\title{
THE EFFECT OF BANK SHOCKS ON FIRM-LEVEL AND AGGREGATE INVESTMENT
}

Working Papers 2015
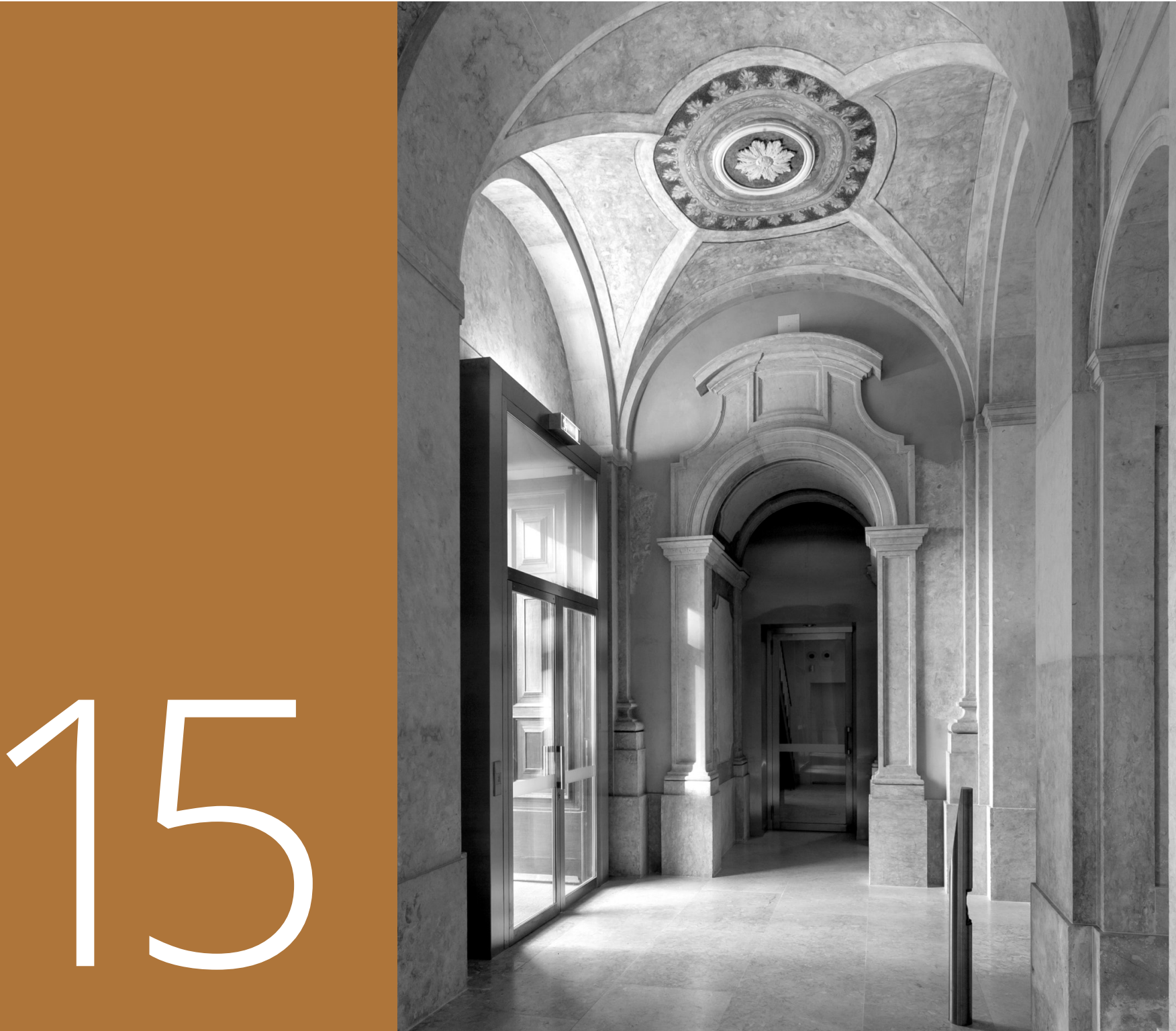



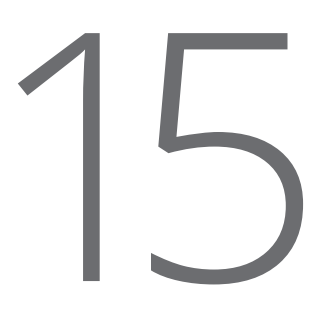

\section{THE EFFECT OF BANK SHOCKS ON FIRM-LEVEL AND AGGREGATE INVESTMENT}

Working Papers 2015

João Amador | Arne J. Nagengast

Please address correspondence to

Banco de Portugal, Economics and Research Department

Av. Almirante Reis 71, 1150-012 Lisboa, Portugal

T+351213130000 | estudos@bportugal.pt

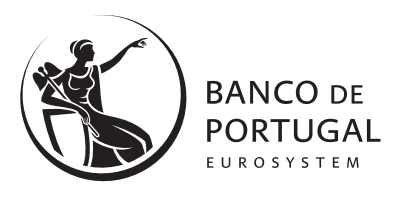

Lisbon, 2015 • www.bportugal.pt 
WORKING PAPERS | Lisbon 2015 • Banco de Portugal Av. Almirante Reis, 71 | 1150-012 Lisboa • www.bportugal.pt • Edition Economics and Research Department • ISBN 978-989-678-388-4 (online) • ISSN 2182-0422 (online) 


\title{
The Effect of Bank Shocks on Firm-Level and Aggregate Investment
}

\author{
João Amador \\ Banco de Portugal \\ Nova SBE
}

\author{
Arne J. Nagengast \\ Deutsche Bundesbank
}

October 2015

\begin{abstract}
We show that credit supply shocks have a strong impact on firm-level as well as aggregate investment by applying the methodology developed by Amiti and Weinstein (2013) to a rich dataset of matched bank-firm loans in the Portuguese economy for the period 2005 to 2013. We argue that their decomposition framework can also be used in the presence of small firms with only one banking relationship as long as they account for a small share of the total loan volume of their banks. The growth rate of individual loans in our dataset is decomposed into bank, firm, industry and common shocks. Adverse bank shocks are found to strongly impair firm-level investment, particularly in small firms and in those with no access to alternative financing sources. For the economy as a whole, granular shocks in the banking system account for around $20-40 \%$ of aggregate investment dynamics.
\end{abstract}

JEL: E32, E44, G21, G32

Keywords: Banks, Credit dynamics, Investment, Firm-level data, Portuguese economy.

Acknowledgements: We thank Andrada Bilan, Diana Bonfim, Sónia Costa, Luisa Farinha, Sudipto Karmakar, Luca Opromolla and Ettore Panetti for helpful comments on an earlier version of this manuscript. Part of the paper was written while Arne J. Nagengast visited the Banco de Portugal whose hospitality is gratefully acknowledged. The views expressed are those of the authors and do not necessarily reflect those of the Banco de Portugal, the Deutsche Bundesbank or the Eurosystem. The usual disclaimers apply.

E-mail: jamador@bportugal.pt; arne.nagengast@bundesbank.de 


\section{Introduction}

Assessing the impact of bank shocks on the real economy has increasingly gained in importance since the 2008 international financial crisis and the subsequent sovereign debt and banking crises in several European countries. In particular, persistently weak investment in front of a backdrop of low bank lending in euro area economies has been a major concern (European Central Bank 2014; Task Force of the Monetary Policy Committee of the ESCB 2015). Although credit dynamics are generally thought to be an important determinant of macroeconomic fluctuations (e.g. Bernanke and Gertler (1995) and Ashcraft (2005)), identifying the origin of variations in credit is hard since the total loan volume in an economy is a function of both credit demand and credit supply.

While initial contributions to identify credit supply shocks were based on aggregate data (e.g. Rosengren and Peek (2000)), more recent studies have made use of the increasing availability of matched bank-firm loan datasets. ${ }^{1}$ These micro-level studies exploit the across-bank variation of an exogenous event affecting bank lending as well as the fact that firms obtain their loans from different credit institutions (Amiti and Weinstein 2011; Chava and Purnanandam 2011; Jimenez et al. 2012; Schnabl 2012; Chodorow-Reich 2014; Iyer et al. 2014; Miyakawa et al. 2015; Dwenger et al. 2015; Kaoru et al. 2015; Paravisini et al. 2015). For example, Khwaja and Mian (2008) use the withdrawal of deposits after the suspension of exchange rate liquidity by the IMF following nuclear tests in Pakistan in 1998 in order to quantify the effect of bank credit supply shocks on the borrowing of firms with different characteristics. The main obstacle for applying the previous approaches to other countries is the difficulty of finding suitable instruments to identify credit supply shocks. Even if these instruments are available, the analysis is usually limited to studying one particular episode. Another shortcoming is that while these studies convincingly address the identification problem at the firm-level, they remain silent on the aggregate effect of credit supply shocks.

All of the three points above are addressed by the methodology proposed by Amiti and Weinstein (2013) (henceforth AW), which exploits the variation of firm borrowing across multiple banks in order to identify credit supply shocks and imposes an adding-up constraint to assure consistency with loan growth at the aggregate level. Since the approach by AW does not rely on instrumental variables, it permits the identification of a wide range of factors affecting bank credit supply such as bankruptcies, regulatory interventions or trading errors for every year in the dataset. The methodology yields a complete decomposition of

1. Hosono and Miyakawa (2015) provide a comprehensive survey of the literature on the identification of adverse shocks to bank lending and their effect on firm activities. 
loan growth rates both at the micro- and macro-level into bank, firm, industry and common shocks.

Our paper applies the methodology by AW to a unique dataset of Portuguese firms and banks for the period 2005 to 2013 and contributes to the literature along three main dimensions. First, AW exclusively focus on the sample of firms listed in the Japanese stock market consisting mainly of large firms with multiple banking relationships, which at first sight appears to be a requirement for the usefulness of the approach. We show that the applicability of the decomposition framework by AW is much more general and that it can also be used for samples that are more representative of the population of firms as a whole, i.e. including a large share of small firms with few bank relationships (Axtell 2001; Cabral and Mata 2003; Khwaja and Mian 2008). This derives from the fact that the imposition of an adding-up constraint introduces weights into the estimation, resulting in bank shocks being identified mainly through lending relations with larger firms, which account for the major part of the total loan volume in Portugal. This insight contributes to bridging the gap between microand macro-level analysis since it implies that credit registry datasets in most countries - which come close to representing the universe of loans in an economy - should be amenable to the estimation methodology by AW.

Second, we show that credit supply shocks have a strong impact on firmlevel investment in the Portuguese economy over and above aggregate demand conditions and firm-specific investment opportunities. In addition, we also consider how the effect of credit supply shocks on investment varies with the capital structure and size of firms. We find that firms with access to alternative financing sources are generally less vulnerable to the adverse effect of bank shocks on investment and partially manage to offset their shortfall of bank credit by increasing their financing from other sources. Larger firms also appear to be in a better position to cope with the unfavourable effects of bank shocks mainly since their banks do not curtail their credit supply as much as for small firms. Our findings on the mitigating effects of alternative financing sources and firm size are in line with studies using other identification strategies and/or focusing on different countries and particular episodes (Khwaja and Mian 2008; Schnabl 2012; Chodorow-Reich 2014; Iyer et al. 2014; Dwenger et al. 2015; Paravisini et al. 2015).

Third, we use the macro-level estimates of bank shocks from our decomposition exercise and show that granular credit supply shocks in the banking system account for around 20 percent of the variation in aggregate lending and between 20 to 40 percent of aggregate investment dynamics in Portugal. The broad coverage of firms in the micro-dataset under consideration as well as the study of a European economy under financial stress and economic adjustment, provide strong support for the findings by AW. Our results contribute to the growing literature on the importance of granular shocks in accounting for macroeconomic fluctuations. Gabaix (2011) demonstrated that in the presence of a fat-tailed firm size distribution idiosyncratic shocks to 
individual large firms do not average out in the aggregate and in the United States explain about one-third of the variation in output growth. Similarly, granular shocks have also been documented to matter for aggregate sales volatility, for example in studies exploiting the variation of exports across destinations (di Giovanni et al. 2014) as well as credit growth in the banking sector using a methodology different from the one by AW (Bremus et al. 2013). A related strand of literature has incorporated banks into dynamic stochastic general equilibrium models (den Heuvel 2008; Gerali et al. 2010; Devereux and Sutherland 2011; Kollmann et al. 2011; Kollmann 2013). In this new class of models negative shocks to bank capital trigger a fall in bank credit which leads to a drop in investment (and output) in line with the results in our study.

The paper is organised as follows. Section 2 outlines the empirical methodology. Section 3 describes our data sources and the salient features of our datasets. Section 4 examines the external validity of our bank shock estimates and investigates their sensitivity to the number of bank relationships. In addition, we characterise our shock estimates by firm-level variables. Section 5 presents our three sets of results and Section 6 concludes.

\section{Empirical Methodology}

Our econometric approach is based on the work by AW, who propose to disentangle loan supply shocks from loan demand shocks in a dataset mainly consisting of firms with multiple bank relationships by exploiting the variation of firm borrowing across different banks. Our exposition begins with a general empirical model capturing the different sources of shocks affecting the bankfirm lending relationship and we will gradually build up the more aggregate specification that is used for computing bank shocks in the Portuguese economy as a whole.

Consider a general class of models in which the growth in lending $L_{f b t}$ by bank $b$ to firm $f$ in time $t$ can be decomposed into a firm-borrowing channel $\alpha_{f t}$ and a bank-lending channel $\beta_{b t}$

$$
\frac{L_{f b t}-L_{f b, t-1}}{L_{f b, t-1}}=\alpha_{f t}+\beta_{b t}+\varepsilon_{f b t},
$$

where we follow the literature in assuming that the expectation of the error term is zero, $E\left[\varepsilon_{f b t}\right]=0$. Equation 1 can be derived structurally (Khwaja and Mian 2008) and its variants have been widely used empirically (Chava and Purnanandam 2011). The underlying assumption of this class of models is that firms cannot fully avoid the negative impact of a reduction in loan supply by its lenders since switching banks is costly, for which there is strong empirical support (Kim et al. 2003).

The firm-borrowing channel $\alpha_{f t}$ captures all factors affecting borrowing that are specific to the firm such as firm-level productivity shocks, firm-specific 
changes in investment opportunities, firm-level changes in access to other financing sources, changes in the credit worthiness of the firm etc. Similarly, the bank-lending channel $\beta_{b t}$ comprises all bank-specific factors that result in a bank to cut back or increase its lending over time. These include factors that have been used in previous studies to identify bank liquidity shocks such as exposure to sovereign debt crises (Chava and Purnanandam 2011), the 2008 global financial crisis (Paravisini et al. 2015), natural disasters (Kaoru et al. 2015) and a nuclear test in Pakistan (Khwaja and Mian 2008). Furthermore, as meticulously documented by AW, there are numerous other events such as regulatory interventions, computer glitches and idiosyncratic trading errors which can have non-negligible effects on the loan supply of banks.

In principle, Equation 1 could be estimated directly using a large set of time-varying bank and firm fixed effects. However, this approach turns out to be inefficient since it ignores the equilibrium relations that underlie the observed outcome in the loan market. Banks can only disburse an additional loan if they find an interested borrower. Correspondingly, firms can only obtain new credit if there is at least one bank that is willing to lend more. Ignoring these constraints yields estimates of bank-lending that are very different from the observed rates of loan growth, which complicates gauging the effect of granular shocks in the banking sector on macroeconomic outcomes. ${ }^{2}$

AW propose introducing a set of adding-up constraints that take into account the equilibrium linkages between banks and firms in the credit market. On the lender side, banks' loan growth is expressed as the bank-lending channel plus the weighted sum of the firm-borrowing channels of its clients by multiplying both sides of Equation 1 by the lagged share of lending to firm $f, \varphi_{f b, t-1}$ and by summing across all firms

$$
\begin{aligned}
& D_{b t}^{B} \equiv \sum_{f}\left(\frac{L_{f b t}-L_{f b, t-1}}{L_{f b, t-1}}\right) \frac{L_{f b, t-1}}{\sum_{f} L_{f b, t-1}} \\
&=\beta_{b t}+\sum_{f} \varphi_{f b, t-1} \alpha_{f t}+\sum_{f} \varphi_{f b, t-1} \varepsilon_{f b t}
\end{aligned}
$$

where

$$
\varphi_{f b, t-1} \equiv \frac{L_{f b, t-1}}{\sum_{f} L_{f b, t-1}},
$$

and $D_{b t}^{B}$ equals the growth rate of lending of bank $b$ to all of its clients. Correspondingly, on the borrower side, firms' loan growth is expressed as the

2. Directly estimating Equation 1 with an unconstrained fixed-effects procedure and using the estimates in a regression on the actual loan growth of banks results in an $R^{2}$ of 0.01 . Weighting the data by loan volume, improves the fit to 0.21 . Using both a weighted regression and a $\log$ specification yields an $R^{2}$ of 0.23 , which still leaves the major part of the variation in the data unexplained. In contrast, the $R^{2}$ is one by construction using the methodology by AW. 
firm-borrowing channel plus the weighted sum of the bank-lending channels by multiplying both sides of equation 1 by the lagged share of borrowing from bank $b, \theta_{f b, t-1}$ and by summing across all banks

$$
\begin{aligned}
D_{f t}^{F} \equiv \sum_{b}\left(\frac{L_{f b t}-L_{f b, t-1}}{L_{f b, t-1}}\right) \frac{L_{f b, t-1}}{\sum_{b} L_{f b, t-1}} \\
=\alpha_{f t}+\sum_{b} \theta_{f b, t-1} \beta_{b t}+\sum_{b} \theta_{f b, t-1} \varepsilon_{f b t},
\end{aligned}
$$

where

$$
\theta_{f b, t-1} \equiv \frac{L_{f b, t-1}}{\sum_{b} L_{f b, t-1}},
$$

and $D_{f t}^{F}$ equals the growth rate of borrowing of firm $f$ from all of its banks.

Note that both $\varphi_{f b, t-1}$ and $\theta_{f b, t-1}$ are pre-determined variables, which allows us to impose the following moment conditions on the data:

$$
E\left[\sum_{f} \varphi_{f b, t-1} \varepsilon_{f b t}\right]=\sum_{f} \varphi_{f b, t-1} E\left[\varepsilon_{f b t}\right]=0,
$$

and

$$
E\left[\sum_{b} \theta_{f b, t-1} \varepsilon_{f b t}\right]=\sum_{b} \theta_{f b, t-1} E\left[\varepsilon_{f b t}\right]=0 .
$$

This yields the following sets of interlinked equations that need to be fulfilled by the parameters $\alpha_{f t}$ and $\beta_{f t}$

$$
D_{b t}^{B}=\beta_{b t}+\sum_{f} \varphi_{f b, t-1} \alpha_{f t}
$$

and

$$
D_{f t}^{F}=\alpha_{f t}+\sum_{b} \theta_{f b, t-1} \beta_{b t} .
$$

For every year equations 4 and 5 comprise a system of $F+B$ linear equations and $F+B$ unknowns, which at first sight suggests that the system has a unique solution. However, since the loan shares by definition sum to one, $\sum_{b} \theta_{f b t}=1$ and $\sum_{f} \varphi_{f b t}=1$, it turns out that the equation system is under-determined, i.e. it has infinitely many solutions. As long as the bankfirm loan network consists of a single connected component - which is the case in our dataset - this means that for any set of $\beta_{b t}$ and $\alpha_{f t}$ that satisfy equations 4 and $5, \beta_{b t}+k_{t}$ and $\alpha_{f t}-k_{t}$ is also a solution. Therefore by imposing one additional constraint standard methods for solving linear equations can be used to obtain a solution as shown in Appendix A.1. In order to arrive at economically meaningful parameters, we follow AW and re-express $\beta_{b t}$ and $\alpha_{f t}$ 
relative to their respective median for every given year as detailed in Appendix A. $2 .^{3}$

Consequently, each bank's lending can be exactly decomposed into the following four terms:

$$
\boldsymbol{D}_{\boldsymbol{t}}^{B}=\left(\bar{A}_{t}+\bar{B}_{t}\right) \iota_{B}+\boldsymbol{\Phi}_{t-1} \boldsymbol{N}_{t}+\boldsymbol{\Phi}_{t-1} \tilde{A}_{t}+\tilde{B}_{t}
$$

where $\boldsymbol{D}_{t}^{B}$ is the $B \times 1$ vector including the loan growth rates of all individual banks at time $t,\left(\bar{A}_{t}+\bar{B}_{t}\right)$ are the median firm and bank shocks, i.e. the common shock affecting all firm-bank relationships in year $t, \iota_{B}$ is a $B \times 1$ vector of 1 's, $N_{t}$ is the $F \times 1$ vector containing the median firm shock in each firm's industry at time $t, \tilde{A}_{t}$ is the $F \times 1$ vector capturing the firm shocks affecting borrowing of individual firms less the median firm shock of the respective industry in year $t, \tilde{\boldsymbol{B}}_{\boldsymbol{t}}$ is the $B \times 1$ vector capturing the bank shocks affecting lending of individual banks less the median bank shock at time $t$, and $\boldsymbol{\Phi}_{\boldsymbol{t}-\mathbf{1}}$ is the $B \times F$ matrix containing the weights of each firm in the lending portfolio of every bank:

$$
\boldsymbol{\Phi}_{\boldsymbol{t}} \equiv\left(\begin{array}{ccc}
\varphi_{11 t} & \ldots & \varphi_{F 1 t} \\
\vdots & \ddots & \vdots \\
\varphi_{1 B t} & \cdots & \varphi_{F B t}
\end{array}\right) .
$$

The first term are common shocks capturing economic forces that affect all lending-borrowing relationships at the same time such as changes in central bank interest rates or changes in aggregate demand conditions. ${ }^{4}$ The second term represents industry shocks which are bank-specific weighted averages of the median firm shock of each industry that the bank is lending to. They capture differences in the credit demand of industries and their impact on bank lending due to differences in their lending portfolio across industries unrelated to the firm-borrowing channel. Third, the firm shock subsumes all factors idiosyncratic to the firm that affect loan demand which cannot be attributed to changes in bank-loan supply. Finally, the last term provides a measure for bank-supply shocks independent of firm-specific, industry-related and economywide conditions. Note that the elements in $\tilde{\boldsymbol{B}}_{t}$ equal the individual bank shocks minus the supply shock of the median bank in year $t$. Suppose bank $b$ was hit by a particularly adverse shock to their credit supply of minus 20 percent while lending in all other banks decreased by only 10 percent. This would, hence, result in a bank shock of minus 10 percent for bank $b$ in this framework since

3. The over-determinacy of the system of linear equations is analogous to the dummy variable trap in linear regression analysis. The solution of expressing the set of coefficients relative to a sample statistic instead of an arbitrarily chosen coefficient also has its counterparts in the dummy variable literature (Suits 1984; Kennedy 1986).

4. Note that the individual contributions deriving from $\bar{A}_{t}$ and $\bar{B}_{t}$ cannot be disentangled given that for any $k_{t}, \beta_{b t}+k_{t}$ and $\alpha_{f t}-k_{t}$ are also solutions to the system of equations under consideration. 
all shocks are always expressed relative to the median bank. Note that while the bank shock exclusively captures supply-side factors, the firm shock subsumes both demand-side and other firm-specific factors such as the riskiness of the firm.

One strength of the framework proposed by AW is that the loan supply shocks of individual banks can be added up using an appropriate weighting scheme in order to express aggregate lending as a function of the four types of shocks described above. Let $w_{b, t}^{B}$ be the share of bank $b$ in total lending in year $t$ and define $\boldsymbol{W}_{\boldsymbol{t}}^{\boldsymbol{B}} \equiv\left[w_{1, t}^{B}, \ldots w_{B, t}^{B}\right]$. Pre-multiplying Equation 6 with $\boldsymbol{W}_{\boldsymbol{t}}^{\boldsymbol{B}}$ allows us to arrive at the following expression for aggregate lending

$$
\begin{aligned}
D_{t}=\boldsymbol{W}_{t-1}^{B} & \boldsymbol{D}_{t}^{B} \\
& =\left(\bar{A}_{t}+\bar{B}_{t}\right)+\boldsymbol{W}_{t-1}^{B} \boldsymbol{\Phi}_{t-1} \boldsymbol{N}_{t}+\boldsymbol{W}_{t-1}^{B} \Phi_{t-1} \tilde{A}_{t}+\boldsymbol{W}_{t-1}^{B} \tilde{B}_{t},
\end{aligned}
$$

where $D_{t}$ is the change in aggregate lending. Analogously to Equation 6, the first term represents the impact of common shocks on aggregate lending. The second term captures granular industry shocks resulting from certain industries having larger shares in the total economy than others. The third term is a granular firm shock deriving from the fact that changes in the credit demand of large firms have a non-negligible effect on aggregate lending. Finally, the fourth term is the granular bank shock which subsumes the weighted average of the credit supply shocks of individual financial institutions. In contrast to the previous literature (Gabaix 2011), estimation of the shocks does not assume their independence and the only requirement is that they are not perfectly correlated.

\section{Data and Descriptive Statistics}

\subsection{Data}

The availability of matched bank-firm loan information is essential for the implementation of the methodology described above. In addition, another requirement is linking the lender-borrower information with other characteristics of the firm. The Portuguese credit registry and balance sheet databases together with the existence of a common firm identifier allow us to construct a very rich micro-level dataset for Portugal for the period 2005-2013.

The Portuguese Central de Riscos de Crédito (Central Credit Register, Portuguese acronym: CRC) provides information on credit exposures. Originally, the purpose of the database was information sharing between participant institutions in order to improve their credit risk assessment and management. The database contains monthly information on loans granted to firms and households, and reporting by all credit institutions is mandatory. For the better part of the paper, we consider only data for the month of December 
to match the Portuguese tax year and the frequency of the balance sheet data. In order to perform an additional econometric analysis on aggregate dynamics we require a larger number of observations and we use data for March, June, September and December for each year in accordance with the quarterly data series for the economy as a whole.

One challenge that arises from working with the credit registry data is to track the identity of banks over time. In particular, banks may go bankrupt and be restructured, be acquired by or merge with another bank. Whenever any of these three events occurred in year $t$, we recoded loans in year $t-1$ as coming from the new institution. ${ }^{5}$ For example, if bank 1 was acquired by bank 2 in year $t$, bank 2's loans in year $t-1$ would be set equal to the sum of the loans of bank 1 and bank 2 . In order to ensure sufficient observations for estimating the bank shocks, we excluded credit institutions with less than ten borrowing relations in both $t$ and $t-1$, which dropped $0.02 \%$ of the observations. The number of banks ranges from 163 to 184 depending on the year, with a smaller number of banks at the end of the sample period.

The balance sheet data for Portuguese firms draws on information reported under Informação Empresarial Simplificada (Simplified Corporate Information, Portuguese acronym: IES). IES is the system through which corporations report mandatory information to the tax administration and the statistical authorities. Data is available from 2005 onwards with a very wide coverage of Portuguese non-financial corporations. ${ }^{6}$ We use information on investment, capital, cash flow, total sales, number of employees, total borrowings, bank loans, bonds, loans from associated firms and liabilities towards shareholders (LTS). ${ }^{7}$ We define investment as the annual difference in capital plus depreciation. As a proxy for Tobin's Q of unlisted firms we use the lagged growth rate of total sales (Whited 2006; Bloom et al. 2007; Kaoru et al. 2015). In 2010 there was a change in the official firm accounting system (from Plano Oficial de Contas (Official Accounting Plan, Portuguese acronym: POC) to Sistema de Normalização Contabilística (Normalised Accounting System, Portuguese acronym: SNC)) which was driven by the need to comply with EU regulations. This leads to small differences in the definitions of total fixed assets, cash flow, total borrowings, bonds and borrowing from associated firms which, however, have a negligible influence on the series under consideration. For the

5. We determine bank mergers and acquisitions in a data-driven manner using the CRC database and defined these events to occur if at least 80 percent of the total loan volume of clients from bank $b$ in year $t-1$ changed to a new institution in year $t$, and bank $b$ was no longer present in the database in year $t$.

6. Sectors such as "financial intermediation", "public administration and defence; compulsory social security" and "extra-territorial organizations and bodies" as well as sole proprietorships are not part of IES.

7. Liabilities towards shareholder include profits attributable to shareholders among other items. 
classification of industries, we use the first two digits of Classifição Portuguesa de Actividades Económicas, Revisão 3 (Portuguese Classification of Economic Activities Revision 3, Portuguese acronym: CAE-Rev.3) which is based on NACE Revision 2 resulting in 78 different industries.

We only consider firms whose number of employees was greater than zero and whose sales and assets were greater than $1000 €$ in a given year. Similarly, only loan volumes larger than $50 €$ were included in the analysis. In order to limit the effect of outliers, the top and the bottom two and a half percentiles of each variable used in the regressions were dropped. Finally, only firms with balance sheet data for three consecutive year can be included in the estimations due to the data requirements for computing lagged sales growth (data for year $t-1$ and $t-2$ ) and investment (data for year $t$ and $t-1$ ). These constraints leave us with a final sample of a total of 187,628 firms ranging from 77,832 to 103,755 depending on the year. The same sample of firms is used for computing the bank shocks from the credit registry data. On average our sample represents $59 \%$ of total employment and $58 \%$ of total sales of the full balance sheet dataset, or equivalently $43 \%$ of the total loan volume of the credit registry data. A large part of the observations is lost because (a) the balance sheet database does not cover sole proprietorships which are part of the credit registry database and (b) not all firms obtain credit from banks and hence are not covered by the credit registry database while they are included in the balance sheet database.

Quarterly data for the total volume of bank loans to non-financial corporations was taken from the Statistical Bulletin of Banco de Portugal. The quarterly investment series for the private sector excluding housing was taken from the National Accounts by Instituto Nacional de Estatística (Portuguese acronym: INE). The aggregate capital stock series was constructed from the gross investment series using the perpetual inventory method. The depreciation rate used corresponds to 10 percent in annual terms and accords with the average rate for Portuguese firms as described in Amador and Soares (2014). The net investment to capital ratio was computed analogously to the firm-level equivalent described above.

\subsection{Stylised Facts and Aggregate Developments in Portugal}

In this section, we first show that investment and loan growth in our sample provide a good approximation to the corresponding aggregates and then we go on to highlight some salient features of the credit registry dataset used for the shock decomposition of loan growth rates.

Figure 1a shows the path of loan growth in our sample as well as in the complete CRC database along with the official data for loans by resident banks to non-financial corporations. For additional detail quarterly instead of annual series are depicted, which are also used in the econometric analysis in Section 5.3. Overall, the dynamics of the complete CRC series and aggregate loan growth are very similar which is not surprising given the coverage of the credit 


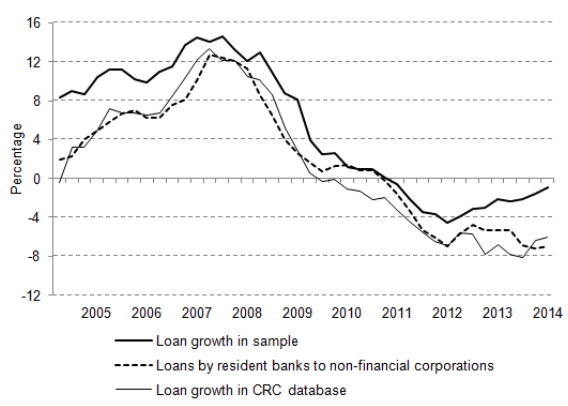

(A) Loan Growth in the Portuguese Economy

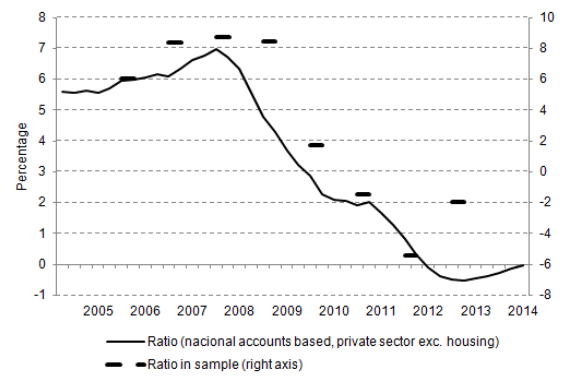

(в) Net Investment-Capital Ratio

Figure 1: Comparison of Macro and Micro Data Series

registry database. Loan growth in our sample also shows a very similar pattern and only diverges slightly from the other two series at the beginning and at the end of the time period. In general, loan growth in our sample appears to be slightly more positive than in the economy as a whole which may partially stem from the need to exclude businesses of sole proprietorship given their absence in the balance sheet database.

Figure $1 \mathrm{~b}$ plots the total net investment over capital of the private sector at a quarterly frequency overlaid with the annual observations from the balance sheet dataset. While net investment increased at the beginning of the sample, it entered a downward trajectory from 2008 onwards. Aggregate investment became so low in 2011 that it was no longer sufficient to compensate the depreciation of the private sectors' capital stock, which only started to recover by the end of 2014. The evolution of the investment series from the balance sheet dataset broadly tracks the aggregate developments although some discrepancies arise due to differences in the definition of the capital stock in national accounts and firms' financial statements as well as the non-exhaustive coverage of firms in the balance sheet data outlined above.

Due to its broad coverage of loans in the Portuguese economy, our matched bank-firm loan dataset has some characteristics that are very different from the one employed in the study by AW, which focuses exclusively on firms listed in the Japanese stock market. The distribution of the number of borrowing relationships per firm is strongly skewed to the right in our sample (Figure 2a). Almost half of all firms borrow only from a single bank, whereas the corresponding number in AW is as low as 2 percent. The shape of the firmbank distribution in our sample is due to the presence of a very large number of small firms, whose borrowing needs do not exceed the level required to offset the cost of maintaining additional borrowing relationships. The large share of small firms in the overall population of firms is a general feature of the firm-size distribution of countries, which can be approximated by different 


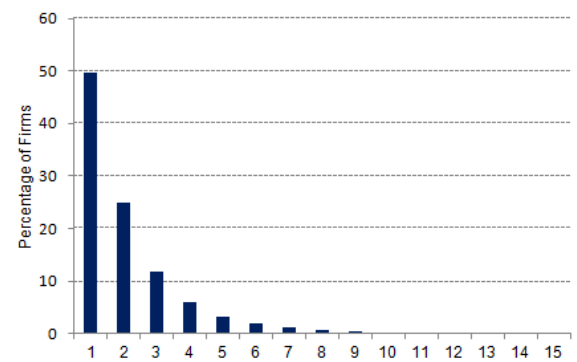

(A) Number of Borrowing Relationships (per Firm)

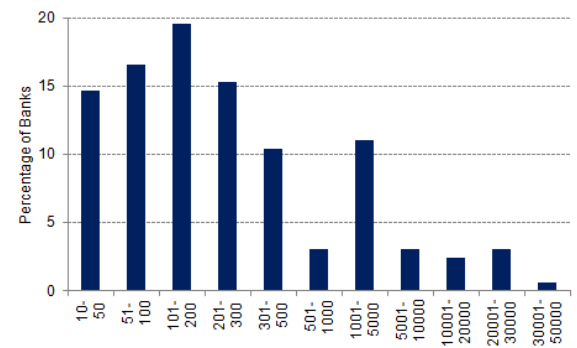

(c) Number of Lending Relationships (per Bank)

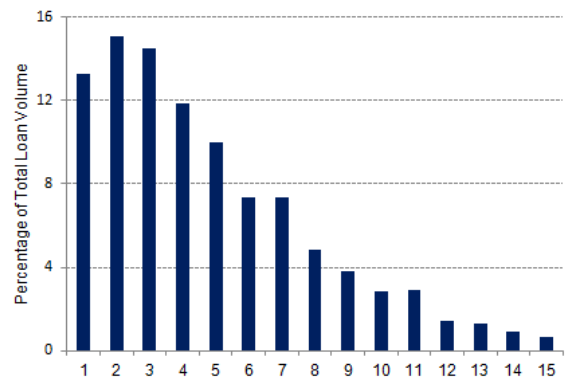

(в) Number of Borrowing Relationships (per Firm)

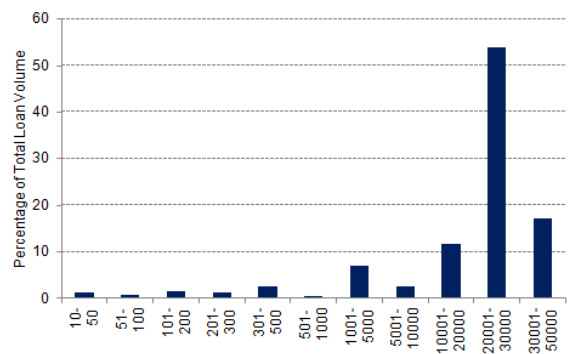

(D) Number of Lending Relationships (per Bank)

Figure 2: Distribution of the Number of Borrowing/Lending Relationships (2013)

classes of right-skewed distributions (Axtell 2001; Cabral and Mata 2003). The large number of firms with only one borrowing relationship is potentially problematic for the estimation of bank shocks, which are mainly identified using the variation of loan growth rates across both banks and firms. However, the total loan volume is much less concentrated in firms with only a single borrowing relationship (Figure $2 \mathrm{~b}$ ). This feature and the characteristics of the estimation methodology will allow us to directly apply the decomposition framework proposed by AW to our dataset (see Section 4.2 for a detailed discussion).

The distribution of the number of firms per bank in our sample is characterised by a large proportion of banks that lend to a small number of firms (Figure 2c). About three quarters of banks have lending relations with less than 1,000 firms. This results from the fact that many credit institutions are small, only active in certain parts of the country and/or specialised in a particular segment of activity. However, as one would expect the share of these banks in the total loan volume is relatively small and accounts for only about 7 percent of total lending (Figure 2d). As a consequence the concentration in the Portuguese banking system is very high with an average Herfindahl index of 0.10 , which 


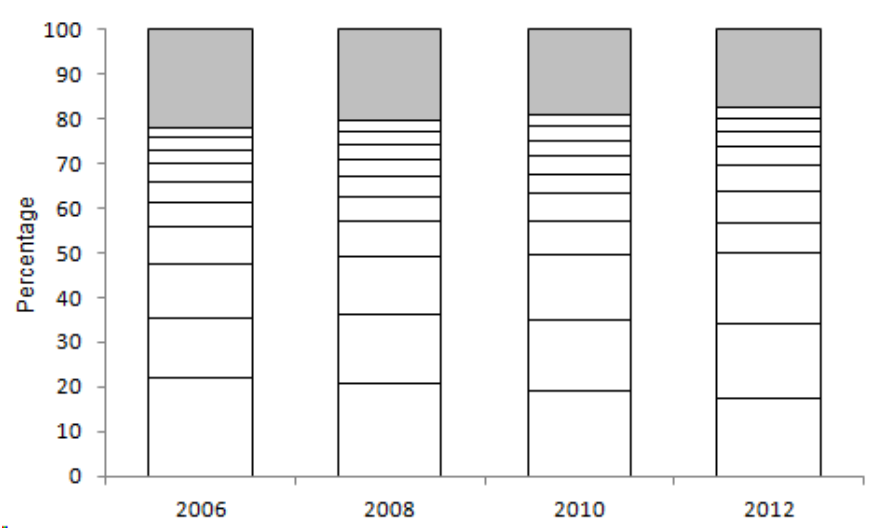

Figure 3: Bank Concentration

Note: The grey block corresponds to the market share of the banks outside the top 10 .

is even more concentrated than the Japanese financial sector studied by AW with an average Herfindahl index of 0.17 . In the sample period the market share of the 10 largest credit institutions has always been above 75 percent, and was as high as 80 percent in 2012 (Figure 3). The high concentration of the banking system is an important prerequisite for the macroeconomic consequences of bank shocks. If some banks are sufficiently large relative to others, then idiosyncratic shocks to these institutions will not average out in the aggregate with a concomitant effect on the aggregate investment rate of the economy.

\section{Estimating Shocks to Bank Lending}

\subsection{External Validity}

In this section, we consider the external validity of the bank shocks obtained from the decomposition of loan growth rates. Due to confidentiality issues we cannot discuss extreme events at individual banks. Instead we focus on the average relation between bank shocks and variables that are commonly thought to affect the bank-lending channel. More specifically, we test whether our bank shock estimates are significantly correlated with proxy variables which have been used in previous studies.

The most common proxy variable for the bank-lending channel is the capital adequacy ratio, which measures a bank's capital relative to its riskweighted credit exposure. In order to protect depositors banking regulators usually require the capital adequacy ratio to stay above a minimum threshold, 
which is $8 \%$ in the case of Portugal. Amiti and Weinstein (2011) and Peek and Rosengren $(1997,2000,2005)$ use the capital adequacy ratio as a proxy variable for the bank-lending channel arguing that banks with low levels of capital adequacy were forced to cut lending in the aftermath of the most recent Japanese stock and house price bubble. Hence, we would expect banks with low capital adequacy ratios to have more negative bank shocks. Similarly, Montgomery and Shimizutani (2009) have suggested that capital injections in Japan have caused bank lending to rise in recipient banks and AW show that capital injections are indeed positively related to bank shocks in Japan. Here, we consider changes in banks' Tier 1 capital and we expect banks with large increases in capital to have more positive bank shocks. Finally, AW consider deteriorations in banks' market-to-book value as a proxy for lower bank lending. As very few firms in Portugal are actually listed in the stock market, we analyse the banks' return on assets and return on equity in lieu of changes in the marketto-book value. We expect banks scoring poorly in any of the two performance measures to have more negative bank shocks.

We define banks with a low capital adequacy ratio to be those in the lowest quartile of our sample characterised by the cut-off $C A R_{b, t}<0.1164$, where $C A R_{b, t}$ denotes the capital adequacy ratio of bank $b$ at time $t$. Similarly, low performing banks are defined to be those in the lowest quartile of our sample in the two performance measures, which corresponds to $R O A_{b, t}<0 \%$ and $R O E_{b, t}<1 \%$, where $R O A_{b, t}$ denotes the return on assets and $R O E_{b, t}$ the return on equity. Banks with large capital increases are defined to be those in the top quartile of the Tier 1 capital growth rate in our sample, which are banks whose capital grows by more than 11.1\%. Table 1 shows that the bank shocks from the decomposition exercise have the expected relation with all four proxy variables. Banks with low capital adequacy ratios have credit supply shocks which are about $6 \mathrm{PP}$ more negative than those of the remaining banks, while for banks with low $R O A_{b, t}$ and $R O E_{b, t}$ the value is about $6 \mathrm{PP}$ and $4 \mathrm{PP}$ lower, respectively. Correspondingly, firms with large capital increases have an associated credit supply shock which is roughly $5 \mathrm{PP}$ more positive than for other banks.

In Table A.1 we show that these results are robust to the use of alternative thresholds. When considering the lowest decile for the capital adequacy ratio as well as the performance measures and the highest decile for increases in capital, the coefficients remain statistically significant and change as one would expect, i.e. they become more negative for the first three variables and more positive for increases in capital. Overall, the fact that our bank shock estimates are related to the four proxy variables of the bank-lending channel in the expected way reassures us that they provide a meaningful measure of actual shocks to the credit supply of banks. Importantly, while here we examined only a small number of possible variables that matter for lending, our bank shocks encompass all sources impacting on the banks' credit supply such as individual mistakes and computer errors (Amiti and Weinstein 2013). 


\begin{tabular}{|c|c|c|c|c|}
\hline Dependent Variable: Bank Shock ${ }_{b, t}$ & $(1)$ & $(2)$ & $(3)$ & $(4)$ \\
\hline Low Capital Adequacy Ratio $_{b, t}$ & $\begin{array}{c}-0.0587^{* * *} \\
(0.0190)\end{array}$ & & & \\
\hline Large Capital Increase $_{b, t}$ & & $\begin{array}{c}0.0496^{* * *} \\
(0.0182)\end{array}$ & & \\
\hline Low Return on Assets $_{b, t}$ & & & $\begin{array}{c}-0.0552^{* *} \\
(0.0216)\end{array}$ & \\
\hline Low Return on Equity $b, t$ & & & & $\begin{array}{c}-0.0460^{* *} \\
(0.0195)\end{array}$ \\
\hline Year fixed effects & Yes & Yes & Yes & Yes \\
\hline Observations & 997 & 1314 & 1128 & 1128 \\
\hline $\mathrm{R}^{2}$ & .015 & .015 & .012 & .01 \\
\hline
\end{tabular}

TABLE 1. Validation of Bank Shocks

Notes: Robust standard errors in parentheses. ${ }^{* * *} \mathrm{p}<0.01,{ }^{* *} \mathrm{p}<0.05{ }^{*} \mathrm{p}<0.1$. We drop the top and bottom two and a half percentiles of bank supply shocks. The capital adequacy ratio is the combined Tier 1 and Tier 2 capital divided by the banks' risk weighted assets. The regressor in Column 1 is a dummy variable equal to 1 if bank $b$ 's capital adequacy ratio is in the lowest quartile of our sample (smaller than 11.6 percent). Capital increases are defined as the growth rate of Tier 1 capital. In Column 2 the regressor is a dummy variable that takes the value 1 if the capital increase of bank $b$ is in the top quartile of our sample (larger than 11.1 percent). Return on assets is defined as the net income of bank $b$ over its average total assets. In Column 3 the regressor is a dummy variable which equals 1 if a bank's return on assets is in the bottom quartile (smaller than 0 percent). Return on equity is defined as the net income of bank $b$ over its net assets. The regressor in Column 4 the regressor is a dummy variable which equals 1 if a bank's return on equity is in the bottom quartile (smaller than 1 percent). All information was taken from bank-level regulatory data collected by Banco de Portugal.

\subsection{Sensitivity to Number of Bank Relationships}

AW use a dataset consisting of Japanese listed companies which are mostly large in size and as a consequence 98 percent of firms in their sample borrow from more than one bank. In contrast, most firms in our dataset are relatively small due to the broad coverage of the Portuguese private sector and hence 50 percent of firms have only one bank relationship. ${ }^{8}$ The identification of loan supply shocks in AW exploits the variation of firm borrowing across different banks and therefore requires the existence of firms with multiple bank relationships. However, due to the moment conditions the estimator proposed by AW also in

8. The high percentage of firms interacting with a single bank is comparable to other studies and is as high as 90 percent in Khwaja and Mian (2008). 
principle allows for the estimation of firm and bank shocks if the underlying dataset includes firms with only a single bank relationship. ${ }^{9}$

In the following, we argue that the empirical strategy by AW can also be used directly to obtain bank shocks in our setting given the particular structure of the dataset under consideration and the characteristics of their proposed estimator. First, note that while half of the firms in our dataset have only one banking relationship, their loans account only for 13 percent of the total loan volume of all banks (Figure $2 \mathrm{~b}$ ). Correspondingly, 72 percent ( 57 percent) of the total loan volume is composed of loans to firms that interact with more than two (three) banks. This is due to the fact that firms with few banking relationships tend to be small and therefore also less likely to request and obtain large loans from their credit institutions. Second, in the empirical methodology outlined in Section 2 bank shocks are computed using weights that, in the case of the banks' loan growth, correspond to the firms' share in total borrowing. As a consequence firms with small loan volumes have a relatively minor influence on the estimation of the loan supply shocks of banks. Combining these two insights implies that direct estimation of bank shocks using our dataset is feasible since their identification mainly occurs via firms with multiple bank relationships as in AW.

In order to empirically assess the impact that firms with few borrowing relationships have on the estimation of shocks to bank lending, we also computed bank shocks for different sub-samples of our dataset including only those firms with more than one, two or three borrowing relationships. In general, we find that bank shocks obtained from these sub-samples are very similar to those using the full sample confirming the intuition described above (Figure 4). The correlation between bank shocks estimated using all firms and those excluding firms with one banking relationship is 0.96. As more firms are dropped from the sample, shocks to firm lending are increasingly attributed to be bank shocks and the correlation with bank shocks from the full sample decreases slightly, but remains generally high.

In the subsequent sections, we present estimation results using bank shocks obtained from the full dataset since this allows us to gauge their effect on investment of the maximum number of firms and also, in particular, of small ones. Nevertheless, our main results also hold if firms with only one borrowing relationship are excluded even though this reduces the sample size by about half.

9. A dummy variable estimation approach requires firms to have at least two bank relationships, as for example in Khwaja and Mian (2008). 

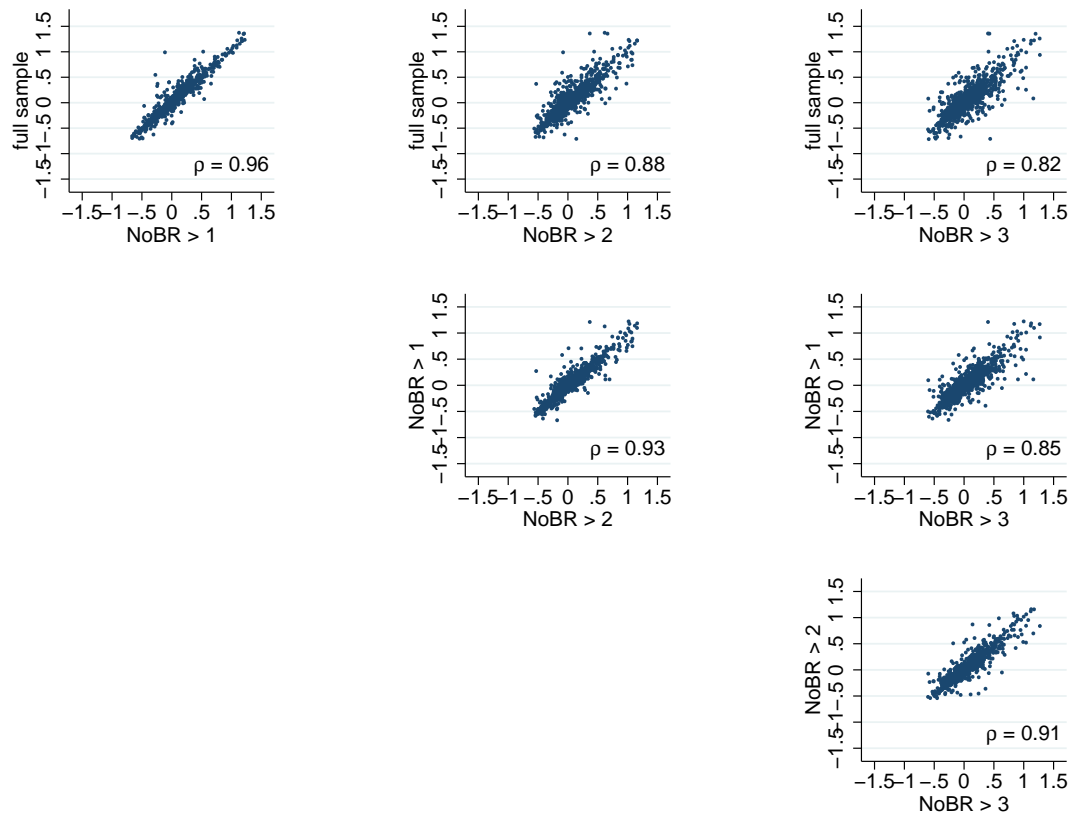

Figure 4: Correlation between Bank Shocks from Different Samples

Notes: NoBR refers to the Number of Borrowing Relationships per Firm. We drop the top and bottom two and a half percentiles of each variable.

\subsection{Bank Shocks, Firm Shocks and Firm-Level Characteristics}

The decomposition of loan growth rates allows us to compute a time-varying measure of bank shocks at the firm-level by weighting the bank-level shocks by the banks' importance in the firms' loan portfolio:

$$
\operatorname{BankShock}_{f t}=\sum_{b} \theta_{f b, t-1} \tilde{\beta}_{b t}
$$

In this section, we briefly examine whether firm shocks and firm-specific bank shocks vary systematically across firms with different characteristics. We consider two features of the firms' loan portfolio - the number of borrowing relationships and the share of loans with short-term maturities (less than a year) - along with two measures of firm size - the number of employees and total sales. In order to assess the variation of bank and firm shocks across firms, we compute the mean of the shocks as well as firm characteristics across the 
sample period and run a number of simple linear regressions. ${ }^{10}$ Our interest is not in causality here, but simply to highlight whether firms with certain characteristics are exposed to smaller or larger shocks than the average firm.

Table 2 shows how bank shocks co-vary with loan portfolio characteristics as well as firm size. We find that all four variables are positively related to bank shocks (Column 1 to Column 4), i.e. larger firms and those with a greater number of borrowing relationships and a higher share of short-term maturities are more likely to be hit by more positive bank shocks. This means that larger firms, which are likely to borrow from several banks, choose or have access to banks that ex-post turn out to be able to supply more credit to their clients. Firms that borrow from an additional bank are on average hit by bank shocks that are 0.007 higher, which in the absence of firm shocks would increase their corresponding loan growth rate by 0.7 PP. Similarly, a large firm with 250 employees is on average faced with a bank shock that is 0.0065 higher than a small firm with 10 employees, ceteris paribus leading to a rise in loan growth by 0.65 PP. After controlling for the number of banking relationships and the maturity structure of firms, larger firms are actually worse off than smaller firms (Column 5 and Column 6). This highlights that the benefit of size accrues mainly through the number of banking relationships. For example, large firms in our dataset also borrow from more specialised credit institutions such as leasing companies that outperformed the median bank in Portugal in the period under investigation.

Table 3 presents the result of the corresponding analysis for the firmborrowing channel. We find that all variables - with the exception of the share of short-term loans - are positively associated with the firm shock (Column 1 to Column 6). Note that differences in bank shocks across firms arise exclusively from firms' bank portfolios, which mechanically translate into differences in the exposure to shocks from different banks. In contrast, differences in firm shocks may result from choices in the past, differential treatment of firms by banks and active intervention by firms to reduce the impact of adverse credit supply shocks. First, the maturity structure of loans modifies the impact of bank shocks which is reflected in differences in the firm-borrowing channel. Firms that have to refinance a larger share of their loans in a given year are much more exposed to adverse credit supply conditions of their banks than those with a higher share of long-term maturities. In addition, firms with very low credit ratings issue more short-term debt (Stohs and Mauer 1996; Diamond 1991; Barclay and Smith 1995) and may be deemed too risky by their banks during a liquidity squeeze. Second, we find evidence that banks pass on a smaller share of liquidity shocks to larger firms. This may be related to information asymmetries (Binks et al. 1992), differences in growth prospects and collateral (Beck et al. 2008)

10. All four independent variables are strongly correlated except with our measure of short-term maturities. 
and preferential treatment by banks (Albertazzi and Marchetti 2010). Third, firms with more borrowing relationships have a more positive firm-borrowing channel even after controlling for the maturity structure and the size of firms (Column 5 and Column 6). This provides evidence that firms may substitute part of their borrowing towards banks that are less affected by negative credit supply shocks in line with the findings by Khwaja and Mian (2008).

\begin{tabular}{|c|c|c|c|c|c|c|}
\hline $\begin{array}{l}\text { Dependent Variable: } \\
\text { Mean Bank Shock } f\end{array}$ & $\begin{array}{c}(1) \\
\text { Full } \\
\text { Sample } \\
\end{array}$ & $\begin{array}{c}(2) \\
\text { Full } \\
\text { Sample } \\
\end{array}$ & $\begin{array}{c}(3) \\
\text { Full } \\
\text { Sample } \\
\end{array}$ & $\begin{array}{c}(4) \\
\text { Full } \\
\text { Sample } \\
\end{array}$ & $\begin{array}{c}(5) \\
\text { Full } \\
\text { Sample } \\
\end{array}$ & $\begin{array}{c}(6) \\
\text { Full } \\
\text { Sample } \\
\end{array}$ \\
\hline Mean Number of Bank Relationships $f$ & $\begin{array}{l}0.00792^{* * *} \\
(0.000129)\end{array}$ & & & & $\begin{array}{c}0.00885^{* * *} \\
(0.000146)\end{array}$ & $\begin{array}{c}0.00936^{* * *} \\
(0.000151)\end{array}$ \\
\hline Mean Share of Short-Term Loans $f$ & & $\begin{array}{c}0.0127^{* * *} \\
(0.000992)\end{array}$ & & & $\begin{array}{l}0.0145^{* * *} \\
(0.000988)\end{array}$ & $\begin{array}{c}0.0145^{* * *} \\
(0.000988)\end{array}$ \\
\hline Mean Log of Employees $f$ & & & $\begin{array}{c}0.00202^{* * *} \\
(0.000186)\end{array}$ & & $\begin{array}{c}-0.00277^{* * *} \\
(0.000211)\end{array}$ & \\
\hline Mean Log of Sales $f$ & & & & $\begin{array}{l}0.00118^{* * *} \\
(0.000139) \\
\end{array}$ & & $\begin{array}{r}-0.00283^{* * *} \\
(0.000163) \\
\end{array}$ \\
\hline $\begin{array}{l}\text { Observations } \\
\mathrm{R}^{2}\end{array}$ & $\begin{array}{l}187628 \\
0.0124\end{array}$ & $\begin{array}{l}164478 \\
0.00142\end{array}$ & $\begin{array}{c}187628 \\
0.000561\end{array}$ & $\begin{array}{c}187628 \\
0.000362 \\
\end{array}$ & $\begin{array}{l}164478 \\
0.0165\end{array}$ & $\begin{array}{l}164478 \\
0.0173 \\
\end{array}$ \\
\hline
\end{tabular}

TABLE 2. Bank Shocks and Firm-Level Characteristics

Notes: Robust standard errors in parentheses. ${ }^{* * *} \mathrm{p}<0.01,{ }^{* *} \mathrm{p}<0.05{ }^{*} \mathrm{p}<0.1$. We drop the top and bottom two and a half percentiles of each variable. Information about the maturity of loans is only available from 2009 onwards.

\begin{tabular}{|c|c|c|c|c|c|c|}
\hline $\begin{array}{l}\text { Dependent Variable: } \\
\text { Mean Firm Shock } f\end{array}$ & $\begin{array}{c}(1) \\
\text { Full } \\
\text { Sample }\end{array}$ & $\begin{array}{c}(2) \\
\text { Full } \\
\text { Sample }\end{array}$ & $\begin{array}{c}(3) \\
\text { Full } \\
\text { Sample }\end{array}$ & $\begin{array}{c}(4) \\
\text { Full } \\
\text { Sample }\end{array}$ & $\begin{array}{c}(5) \\
\text { Full } \\
\text { Sample }\end{array}$ & $\begin{array}{c}(6) \\
\text { Full } \\
\text { Sample }\end{array}$ \\
\hline Mean Number of Bank Relationships $f$ & $\begin{array}{l}0.0213^{* * *} \\
(0.000552)\end{array}$ & & & & $\begin{array}{l}0.0104^{* * *} \\
(0.000624)\end{array}$ & $\begin{array}{c}0.00583^{* * *} \\
(0.000644)\end{array}$ \\
\hline Mean Share of Short-Term Loans $f$ & & $\begin{array}{c}-0.168^{* * *} \\
(0.00401)\end{array}$ & & & $\begin{array}{c}-0.164^{* * *} \\
(0.00399)\end{array}$ & $\begin{array}{c}-0.165^{* * *} \\
(0.00399)\end{array}$ \\
\hline Mean Log of Employees $f$ & & & $\begin{array}{l}0.0333^{* * *} \\
(0.000810)\end{array}$ & & $\begin{array}{c}0.0267^{* * *} \\
(0.000917)\end{array}$ & \\
\hline Mean Log of Sales $f$ & & & & $\begin{array}{c}0.0302^{* * *} \\
(0.000598)\end{array}$ & & $\begin{array}{l}0.0266^{* * *} \\
(0.000705)\end{array}$ \\
\hline $\begin{array}{l}\text { Observations } \\
\mathrm{R}^{2}\end{array}$ & $\begin{array}{l}187628 \\
0.00504\end{array}$ & $\begin{array}{l}164478 \\
0.0143\end{array}$ & $\begin{array}{l}187628 \\
0.00852\end{array}$ & $\begin{array}{l}187628 \\
0.0132\end{array}$ & $\begin{array}{l}164478 \\
0.0247\end{array}$ & $\begin{array}{l}164478 \\
0.0288\end{array}$ \\
\hline
\end{tabular}

TABle 3. Firm Shocks and Firm-Level Characteristics

Notes: Robust standard errors in parentheses. ${ }^{* * *} \mathrm{p}<0.01,{ }^{* *} \mathrm{p}<0.05{ }^{*} \mathrm{p}<0.1$. We drop the top and bottom two and a half percentiles of each variable. Information about the maturity of loans is only available from 2009 onwards. 


\section{The Effects of Bank Shocks on Investment}

In the subsequent sections, first, we examine the influence of bank shocks on firm-level investment (Section 5.1). Second, we investigate whether the capital structure and size of firms affects the impact that bank shocks have on firmlevel outcomes (Section 5.2). Finally, we quantify the effects of bank shocks on aggregate loan and investment dynamics (Section 5.3).

\subsection{Baseline Results}

In order to quantify the effect of bank shocks on firm investment, we use a standard investment regression framework with cash flow and lagged sales growth, which is a commonly used proxy for Tobin's Q of unlisted firms (Whited 2006; Bloom et al. 2007; Kaoru et al. 2015). In addition, we always include firm and year fixed effects to control for unobserved firm-level characteristics as well as common time-varying factors affecting investment in all firms.

Table 4 presents our baseline results along with a number of robustness tests and alternative specifications. In line with the literature, we find a positive association between a firm's investment and its cash flow and investment opportunities. In Column 2 we add the bank shock, firm shock and industry shock from the decomposition of firm borrowing. ${ }^{11}$ Since not all firms borrow from banks to the same extent, the effect that bank shocks have on investment is likely to differ as a function of firms' dependence on bank loans. For example, a given bank shock will affect firms that borrow very little from banks relative to their size much less than firms that depend almost entirely on bank financing. In order to account for these differences in bank dependence, we include interaction terms with the mean ratio of bank loans to total assets. ${ }^{12}$ Column 2 of Table 4 shows that the coefficient on bank shocks interacted with the mean loan-to-asset ratio is positive indicating that a stronger exposure to bank loans is associated with a more pronounced effect of bank shocks. We also find a positive coefficient on bank shocks entering alone, which means that even firms with few bank loans would have financed more investment projects in the absence of negative shocks to their banks' credit supply. As expected, both the firm borrowing shock and its interaction with the mean bank-loan-to-asset ratio show a positive coefficient. This implies that the firm-borrowing channel, for example capturing changes in the marginal product of capital or changes in the credit worthiness of the firm, has a strong impact on investment which is more pronounced for firms which are highly dependent on the supply of bank credit. Similarly, we find a positive coefficient for the industry shock suggesting

11. We cannot separately include the common shock since it does not vary across firms and therefore is already absorbed in the year fixed effect.

12. Since the mean bank-loan-to-asset ratio is time invariant, we cannot include it separately in the regression since it is already absorbed in the firm fixed effect. 
that investment opportunities often arise at the level of particular industries. For example, these might be related to the price of industry-specific investment goods, or demand and productivity shocks that are shared by all firms within the same industry.

\begin{tabular}{|c|c|c|c|c|c|}
\hline $\begin{array}{l}\text { Dependent Variable: } \\
\text { Investment } f, t / \text { Capital }_{f, t-1}\end{array}$ & $\begin{array}{c}(1) \\
\text { Full } \\
\text { Sample } \\
\end{array}$ & $\begin{array}{c}(2) \\
\text { Full } \\
\text { Sample } \\
\end{array}$ & $\begin{array}{c}(3) \\
\text { Largest } \\
\text { firms }\end{array}$ & $\begin{array}{c}(4) \\
\text { NoBR }>1\end{array}$ & $\begin{array}{c}(5) \\
\text { NoBR }>1 \\
\text { combined } \\
\end{array}$ \\
\hline Cash Flow $_{f, t} /$ Capital $_{f, t-1}$ & $\begin{array}{l}0.0260^{* * *} \\
(0.000403)\end{array}$ & $\begin{array}{l}0.0257^{* * *} \\
(0.000404)\end{array}$ & $\begin{array}{c}0.00385^{* * *} \\
(0.00102)\end{array}$ & $\begin{array}{l}0.0381^{* * * *} \\
(0.000783)\end{array}$ & $\begin{array}{l}0.0258^{* * *} \\
(0.000405)\end{array}$ \\
\hline Sales Growth $_{f, t-1}$ & $\begin{array}{l}0.0388^{* * *} \\
(0.00190)\end{array}$ & $\begin{array}{r}0.0295^{* * *} \\
(0.00186)\end{array}$ & $\begin{array}{c}0.00104 \\
(0.00487)\end{array}$ & $\begin{array}{l}0.0251^{* * *} \\
(0.00243)\end{array}$ & $\begin{array}{r}0.0290^{* * *} \\
(0.00186)\end{array}$ \\
\hline Bank Shock $_{f, t}$ & & $\begin{array}{l}0.146^{* * *} \\
(0.00835)\end{array}$ & $\begin{array}{c}0.0396 \\
(0.0628)\end{array}$ & $\begin{array}{l}0.214^{* * *} \\
(0.0131)\end{array}$ & $\begin{array}{l}0.157^{* * *} \\
(0.00897)\end{array}$ \\
\hline $\begin{array}{l}\left(\text { Bank Shock }_{f, t}\right)^{*} \\
(\text { Mean Bank-Loan-to-Asset Ratio } f)\end{array}$ & & $\begin{array}{l}0.147^{* * *} \\
(0.0259)\end{array}$ & $\begin{array}{l}0.301^{* *} \\
(0.143)\end{array}$ & $\begin{array}{l}0.0758 * * \\
(0.0354)\end{array}$ & $\begin{array}{l}0.145^{* * *} \\
(0.0272)\end{array}$ \\
\hline Firm Shock $_{f, t}$ & & $\begin{array}{l}0.133^{* * *} \\
(0.00277)\end{array}$ & $\begin{array}{r}0.137^{* * *} \\
(0.0156)\end{array}$ & $\begin{array}{l}0.172^{* * *} \\
(0.00382)\end{array}$ & $\begin{array}{l}0.133^{* * *} \\
(0.00284)\end{array}$ \\
\hline $\begin{array}{l}\left(\text { Firm Shock }_{f, t}\right)^{*} \\
(\text { Mean Bank-Loan-to-Asset Ratio } f)\end{array}$ & & $\begin{array}{c}0.142^{* * *} \\
(0.0142)\end{array}$ & $\begin{array}{c}0.0451 \\
(0.0419)\end{array}$ & $\begin{array}{c}0.130^{* * *} \\
(0.0142)\end{array}$ & $\begin{array}{c}0.144^{* * *} \\
(0.0148)\end{array}$ \\
\hline Industry shock $_{f, t}$ & & $\begin{array}{l}0.498^{* * *} \\
(0.0293) \\
\end{array}$ & $\begin{array}{l}0.141^{* * *} \\
(0.0545) \\
\end{array}$ & $\begin{array}{l}0.433^{* * *} \\
(0.0398) \\
\end{array}$ & $\begin{array}{l}0.518^{* * *} \\
(0.0304)\end{array}$ \\
\hline \multicolumn{6}{|l|}{ Fixed Effects } \\
\hline Year & Yes & Yes & Yes & Yes & Yes \\
\hline Firm & Yes & Yes & Yes & Yes & Yes \\
\hline Observations & 656246 & 656246 & 21415 & 329892 & 655529 \\
\hline $\mathrm{R}^{2}$ & 0.356 & 0.388 & 0.418 & 0.437 & 0.389 \\
\hline
\end{tabular}

TABLE 4. Firm-Level Investment

Notes: Robust standard errors in parentheses. ${ }^{* * *} \mathrm{p}<0.01,{ }^{* *} \mathrm{p}<0.05{ }^{*} \mathrm{p}<0.1$. We drop the top and bottom two and a half percentiles of each variable. The mean bank-loan-to-asset ratio is defined for each firm as its average ratio of bank loans to assets over the sample period. NoBR refers to the Number of Borrowing Relationships per firm.

Our results strongly support the findings by AW in particular due to the fact that the datasets differ considerably from each other: While AW focus on the set of Japanese firms listed on the Japanese stock exchange, our sample covers almost 200,000 Portuguese firms, which in large part are relatively small and unlisted. Although our main findings are very similar, AW find a negative coefficient on the main effect for bank shocks while its interaction with the mean bank-loan-to-asset ratio is positive. AW argue that negative bank shocks may have a positive impact on the investment of firms that do not rely heavily on bank loans since they may undertake investment projects of competitors if the latter are short of credit (Buera et al. 2014). For comparison purposes we attempt to match the sample of AW as closely as possible by including only 
the largest firms in our dataset. ${ }^{13}$ We repeat the decomposition exercise using this sub-sample and in Column 3 we present the results for this additional analysis. In this case, we find that the coefficient on bank shocks is statistically indistinguishable from zero. This suggests that the differences in the effects of bank shocks might be related to differences in the firms included in two datasets. Very large firms may be more likely to benefit relative to other firms when credit conditions tighten, while small firms lack alternative financing sources and may generally struggle in the presence of adverse financing conditions even if their exposure to bank loans is relatively low. The coefficients of the remaining variables do not change sign, but tend to become more similar in magnitude to the ones obtained by AW. Bank shocks interacted with the mean bank-loan-toasset ratio become more important, while firm shocks become less important. Similarly, the coefficient on industry shocks is lower indicating that industry dynamics seem to be slightly less important than for smaller firms.

As discussed in Section 4.2 one potential concern pertains to the estimation of bank shocks using a dataset consisting in large part of firms with only a single banking relationship. In Column 4, we repeat the analysis including only those firms interacting with at least two different banks. ${ }^{14}$ We find that none of the coefficients changes appreciably despite the fact that this intervention reduces the sample size by about half. The differences in the coefficients between Column 2 and Column 4 may derive either from differences in the sample of firms in the investment regression or from differences in the estimated bank and firm shocks. In order to disentangle these two explanations, we combine the bank shocks obtained from the reduced sample with the full dataset. ${ }^{15}$ This allows us to leverage the bank shock estimates from the sub-sample, which are unaffected by the criticism raised above, and use them with the complete dataset due to the fact that (most) banks lend to firms in both samples. Column 5 presents the results of this additional analysis whose sample size is very similar to the one used in our baseline specification in Column 2. Strikingly, none of the coefficients from this exercise is statistically significantly different from the ones in our baseline specification suggesting that the small

13. For this analysis we define the largest firms to be those in the top three percentile of loan volume each year, which gives us a sample size comparable to the one by AW.

14. Similar results are obtained when dropping firms with less than three borrowing relationships.

15. Denote the vector of bank shocks estimated from the sample excluding firms with only one borrowing relationship by $\boldsymbol{B}_{\boldsymbol{t}}^{\boldsymbol{I}}$. For simplicity, assume that $\boldsymbol{B}_{\boldsymbol{t}}^{\boldsymbol{I}}$ and $\boldsymbol{B}_{\boldsymbol{t}}$ have the same dimensions. In practice, the full sample has on average six banks per year more than the sub-sample, whose bank shocks were set to zero. This allows for the computation of firm shocks for the full sample as $A_{t}=D_{t}^{F}-\Theta_{t-1} B_{t}^{I}$, where $A_{t}$ is the vector of firm shocks in the full sample, $D_{t}^{F}$ is the vector of loan growth rates of the full sample, and $\Theta_{t-1}$ are the firm-borrowing weights of the full sample. Similarly, firm-specific bank shocks are obtained by pre-multiplying $B_{t}^{I}$ with $\Theta_{t-1}$. The normalisation of all variables is then performed analogously to the one in the full sample. 
discrepancies between the coefficients in Column 2 and Column 4 are not related to the estimation of bank shocks. Overall, these robustness tests provide strong support for applying the decomposition framework by AW to samples including firms with few borrowing relationships, which is a characteristic of many matched bank-firm loan datasets as, for example, in Khwaja and Mian (2008).

\subsection{Firm Heterogeneity}

In this section we investigate whether the effect of bank shocks on investment varies with the capital structure as well as the size of firms. One hypothesis is that firms with access to financing sources other than bank loans might be less susceptible to adverse bank-supply shocks. For example, Adrian et al. (2012) provide empirical evidence on firms compensating the decline in bank lending by increasing their borrowing in the bond market. Similarly, access to internal sources of capital has been shown to shield affiliates of multinational enterprises from the real effects of currency and banking crisis (Klein et al. 2002; Desai et al. 2008). Given the small size and ownership structure of many Portuguese firms liabilities towards shareholders may provide another potential source of financing when external capital is scarce (Romano et al. 2001).

Table 5 presents the results of interacting bank and firm shock variables with the mean ratio of other loans (i.e. those coming from sources other than banks), bonds, intra-group loans and liabilities towards shareholders over total assets. The coefficient on the interaction with bank loans is negative and statistically significant for other loans and debt from shareholders, while the coefficients for bonds and intra-group loans are statistically indistinguishable from zero. Similarly, the coefficients on the interaction of all capital structure variables with the firm shock with the exception of the one for bonds are also negative and significant. In terms of their size firm-specific reductions in credit appear to have a similar effect to those that are bank-specific. Overall, firms with access to alternative sources of capital seem to be less likely to curtail their investment when hit by adverse shocks to their borrowing. Firms with access to other sources of financing could either be partially shielded from bank shocks since they generally finance a part of their investment projects in this way or because they tap these sources increasingly during financial distress in the banking sector. In order to differentiate between these two possibilities we run another set of regressions including interactions of the bank shock with both changes in other financing sources as well as the lag of access to other financing sources. Table 6 shows that the coefficients of the interaction of both the difference and the lag of alternative financing sources with the bank shock are negative and significant with the exception of bond financing. This suggests that both mechanisms shield firms from a lower credit supply in the banking sector. First, firms that have access to alternative financing sources can substitute bank loans if necessary and are therefore less vulnerable to the curtailment of credit by 


\begin{tabular}{|c|c|c|c|c|c|}
\hline $\begin{array}{l}\text { Dependent Variable: } \\
\text { Investment } f, t / \text { Capital }_{f, t-1}\end{array}$ & $\begin{array}{c}(1) \\
\text { Full } \\
\text { Sample }\end{array}$ & $\begin{array}{c}(2) \\
\text { Full } \\
\text { Sample }\end{array}$ & $\begin{array}{c}(3) \\
\text { Full } \\
\text { Sample }\end{array}$ & $\begin{array}{c}(4) \\
\text { Full } \\
\text { Sample }\end{array}$ & $\begin{array}{c}(5) \\
\text { Full } \\
\text { Sample }\end{array}$ \\
\hline Cash Flow $f, t_{\text {/ Capital }}, t-1$ & $\begin{array}{l}0.0258^{* * *} \\
(0.000404)\end{array}$ & $\begin{array}{l}0.0257^{* * *} \\
(0.000404)\end{array}$ & $\begin{array}{l}0.0257^{* * *} \\
(0.000404)\end{array}$ & $\begin{array}{l}0.0257^{* * *} \\
(0.000404)\end{array}$ & $\begin{array}{l}0.0258^{* * *} \\
(0.000404)\end{array}$ \\
\hline Sales Growth $_{f, t-1}$ & $\begin{array}{l}0.0296^{* * *} \\
(0.00186)\end{array}$ & $\begin{array}{l}0.0295^{* * *} \\
(0.00186)\end{array}$ & $\begin{array}{r}0.0296^{* * *} \\
(0.00186)\end{array}$ & $\begin{array}{r}0.0296^{* * *} \\
(0.00186)\end{array}$ & $\begin{array}{r}0.0296^{* * *} \\
(0.00186)\end{array}$ \\
\hline Bank Shock $_{f, t}$ & $\begin{array}{l}0.152^{* * *} \\
(0.00903)\end{array}$ & $\begin{array}{l}0.146^{* * *} \\
(0.00848)\end{array}$ & $\begin{array}{c}0.149^{* * *} \\
(0.00873)\end{array}$ & $\begin{array}{l}0.159^{* * *} \\
(0.00931)\end{array}$ & $\begin{array}{l}0.159^{* * *} \\
(0.00942)\end{array}$ \\
\hline $\begin{array}{l}\left(\text { Bank Shock }_{f, t}\right)^{*} \\
(\text { Mean Bank-Loan-to-Asset Ratio } f)\end{array}$ & $\begin{array}{c}0.153^{* * *} \\
(0.0264)\end{array}$ & $\begin{array}{r}0.147^{* * *} \\
(0.0261)\end{array}$ & $\begin{array}{r}0.150^{* * *} \\
(0.0261)\end{array}$ & $\begin{array}{c}0.150^{* * *} \\
(0.0260)\end{array}$ & $\begin{array}{l}0.151^{* * *} \\
(0.0263)\end{array}$ \\
\hline Firm Shock $_{f, t}$ & $\begin{array}{c}0.138^{* * *} \\
(0.00289)\end{array}$ & $\begin{array}{c}0.133^{* * *} \\
(0.00277)\end{array}$ & $\begin{array}{c}0.135^{* * *} \\
(0.00283)\end{array}$ & $\begin{array}{l}0.141^{* * *} \\
(0.00296)\end{array}$ & $\begin{array}{c}0.142^{* * *} \\
(0.00297)\end{array}$ \\
\hline $\begin{array}{l}\left(\text { Firm Shock }_{f, t}\right)^{*} \\
(\text { Mean Bank-Loan-to-Asset Ratio } f)\end{array}$ & $\begin{array}{l}0.148^{* * *} \\
(0.0147)\end{array}$ & $\begin{array}{l}0.142^{* * *} \\
(0.0144)\end{array}$ & $\begin{array}{r}0.145^{* * *} \\
(0.0144)\end{array}$ & $\begin{array}{r}0.145^{* * *} \\
(0.0143)\end{array}$ & $\begin{array}{c}0.147^{* * *} \\
(0.0145)\end{array}$ \\
\hline $\begin{array}{l}\left(\text { Bank Shock }_{f, t}\right)^{*} \\
(\text { Mean Other-Loan-to-Asset Ratio } f)\end{array}$ & $\begin{array}{l}-0.104^{* *} \\
(0.0485)\end{array}$ & & & & $\begin{array}{l}-0.0112 \\
(0.0573)\end{array}$ \\
\hline $\begin{array}{l}\left(\text { Bank Shock }_{f, t}\right)^{*} \\
(\text { Mean Bonds-to-Asset Ratio } f)\end{array}$ & & $\begin{array}{c}0.0115 \\
(0.0724)\end{array}$ & & & \\
\hline $\begin{array}{l}\left(\text { Bank Shock }_{f, t}\right)^{*} \\
(\text { Mean Intra-Group-Loan-to-Asset Ratio } f \text { ) }\end{array}$ & & & $\begin{array}{l}-0.0824 \\
(0.0590)\end{array}$ & & \\
\hline $\begin{array}{l}\left(\text { Bank Shock }_{f, t}\right)^{*} \\
(\text { Mean LTS-to-Asset Ratio } f)\end{array}$ & & & & $\begin{array}{c}-0.140^{* * *} \\
(0.0400)\end{array}$ & $\begin{array}{c}-0.135^{* * *} \\
(0.0472)\end{array}$ \\
\hline $\begin{array}{l}\left(\text { Firm Shock }_{f, t}\right)^{*} \\
(\text { Mean Other-Loan-to-Asset Ratio } f)\end{array}$ & $\begin{array}{c}-0.0917^{* * *} \\
(0.0130)\end{array}$ & & & & $\begin{array}{c}-0.0334^{* *} \\
(0.0156)\end{array}$ \\
\hline $\begin{array}{l}\left(\text { Firm Shock }_{f, t}\right)^{*} \\
(\text { Mean Bonds-to-Asset Ratio } f)\end{array}$ & & $\begin{array}{r}-0.00558 \\
(0.0182)\end{array}$ & & & \\
\hline $\begin{array}{l}\left(\text { Firm Shock }_{f, t}\right)^{*} \\
(\text { Mean Intra-Group-Loan-to-Asset Ratio } f \text { ) }\end{array}$ & & & $\begin{array}{c}-0.0565^{* * *} \\
(0.0154)\end{array}$ & & \\
\hline $\begin{array}{l}\left(\text { Firm Shock }_{f, t}\right)^{*} \\
(\text { Mean LTS-to-Asset Ratio } f)\end{array}$ & & & & $\begin{array}{c}-0.0989^{* * *} \\
(0.0106)\end{array}$ & $\begin{array}{c}-0.0831^{* * *} \\
(0.0127)\end{array}$ \\
\hline Industry shock $_{f, t}$ & $\begin{array}{l}0.497^{* * *} \\
(0.0292) \\
\end{array}$ & $\begin{array}{l}0.498^{* * *} \\
(0.0293)\end{array}$ & $\begin{array}{l}0.498^{* * *} \\
(0.0293)\end{array}$ & $\begin{array}{l}0.494^{* * *} \\
(0.0293)\end{array}$ & $\begin{array}{l}0.495^{* * *} \\
(0.0293)\end{array}$ \\
\hline \multicolumn{6}{|l|}{ Fixed Effects } \\
\hline Year & Yes & Yes & Yes & Yes & Yes \\
\hline Firm & Yes & Yes & Yes & Yes & Yes \\
\hline Observations & 656246 & 656246 & 656246 & 656246 & 656246 \\
\hline $\mathrm{R}^{2}$ & 0.388 & 0.388 & 0.388 & 0.389 & 0.389 \\
\hline
\end{tabular}

Table 5. Firm-Level Investment - Capital Structure

Notes: Robust standard errors in parentheses. ${ }^{* * *} \mathrm{p}<0.01,{ }^{*} \mathrm{p}<0.05{ }^{*} \mathrm{p}<0.1$. We drop the top and bottom two and a half percentiles of each variable. The Mean Bank-Loan-to-Asset Ratio is defined for each firm as its average ratio of bank loans to assets over the sample period. The ratios for Other Loans, Bonds, Intra-Group Loans and Liabilities towards Shareholders (LTS) are defined analogously. 
their credit institutions. Second, access to other financing sources mitigates the impact of adverse bank shocks on investment more generally since these firms appear to depend less on bank loans for their investments in the first place.

The coefficient on the bank shock interaction with other loans and shareholder debt has the opposite sign and roughly the same magnitude of the one for the interaction of the bank shock with the mean bank-loan-toasset ratio. This implies that the exposure of firms' to bank shocks deriving from one euro of bank debt can be offset by roughly one euro borrowed from other sources. How many firms do actually benefit from the mitigating effect of alternative funding sources? In our sample, $52 \%$ of firms have access to some kind of other loan and $46 \%$ of firms have liabilities towards their shareholders, while $71 \%$ of firms have at least one of the two on their balance sheet. As one would expect, the bond market does not play an important role for the majority of firms in Portugal and only about $2 \%$ of firms in our sample issue bonds in the Portuguese capital market. Out of those firms with some kind of other loan, the median firm has a mean other-loan-to-asset ratio of about $9 \%$ and a mean bank-loan-to-asset ratio of $16 \%$. Similarly, out of the firms with some kind of shareholder liability, the median firm has a mean LTS-to-asset ratio of $13 \%$, while the mean bank-loan-to-asset ratio stands at $15 \%$. However, a large proportion of firms in Portugal are almost entirely dependent on bankfinancing ${ }^{16}$ and hence the majority of firms feels the full brunt of bank shocks on their investment activities.

An additional analysis contributes to the ongoing debate in the literature on how firms of different sizes respond to financial shocks. There is some evidence that larger firms are better able to cope with declines in their banks' credit supply (Khwaja and Mian 2008; Sharpe 1994). In Section 4.3 we already established that large firms are less likely to be hit by adverse bank shocks due to the credit institutions they chose to interact with. Here, we ask the question whether the response of investment to the same bank shock differs as a function of firm size. We use the European Commission's definition of firm size and consider firms to be large if they employ more than 50 persons and if their annual turnover exceeds $€ 10$ million. ${ }^{17}$ Column 1 and Column 2 of Table 7 present the results of regressions including the interaction of bank and firm shocks with our two measures of firm size. The coefficient on the interaction between firm size and bank shocks is negative and significant for both measures of firm size. This means that large firms curtail their investment

16. The median firm in the dataset has a mean bank-loan-to-asset ratio of $14 \%$, while the corresponding values for other loans and liabilities towards shareholders are as low as $3 \%$ and $5 \%$, respectively.

17. This corresponds to the European Commission's threshold for medium-sized enterprises, which is relatively high given the size of Portugal. This leaves us with 7,678 firms (or $4 \%$ of our sample) being defined as large when using employment as the threshold and 4,413 firms (or $2.4 \%$ of our sample) when using total sales. 


\begin{tabular}{|c|c|c|c|c|c|}
\hline $\begin{array}{l}\text { Dependent Variable: } \\
\text { Investment }_{f, t} / \text { Capital }_{f, t-1}\end{array}$ & $\begin{array}{c}(1) \\
\text { Full } \\
\text { Sample }\end{array}$ & $\begin{array}{c}(2) \\
\text { Full } \\
\text { Sample }\end{array}$ & $\begin{array}{c}(3) \\
\text { Full } \\
\text { Sample }\end{array}$ & $\begin{array}{c}(4) \\
\text { Full } \\
\text { Sample }\end{array}$ & $\begin{array}{c}(5) \\
\text { Full } \\
\text { Sample }\end{array}$ \\
\hline Cash Flow $f, t_{\text {/ }}$ Capital $_{f, t-1}$ & $\begin{array}{l}0.0258^{* * *} \\
(0.000405)\end{array}$ & $\begin{array}{l}0.0257^{* * *} \\
(0.000404)\end{array}$ & $\begin{array}{l}0.0257^{* * *} \\
(0.000405)\end{array}$ & $\begin{array}{l}0.0257^{* * *} \\
(0.000404)\end{array}$ & $\begin{array}{l}0.0258^{* * *} \\
(0.000405)\end{array}$ \\
\hline Sales Growth $_{f, t-1}$ & $\begin{array}{r}0.0296^{* * *} \\
(0.00186)\end{array}$ & $\begin{array}{l}0.0295^{* * *} \\
(0.00186)\end{array}$ & $\begin{array}{l}0.0296^{* * *} \\
(0.00186)\end{array}$ & $\begin{array}{l}0.0293^{* * *} \\
(0.00186)\end{array}$ & $\begin{array}{r}0.0293^{* * *} \\
(0.00186)\end{array}$ \\
\hline Bank Shock $_{f, t}$ & $\begin{array}{l}0.151^{* * *} \\
(0.00853)\end{array}$ & $\begin{array}{l}0.146^{* * *} \\
(0.00836)\end{array}$ & $\begin{array}{l}0.150^{* * *} \\
(0.00841)\end{array}$ & $\begin{array}{l}0.150^{* * *} \\
(0.00887)\end{array}$ & $\begin{array}{l}0.155^{* * *} \\
(0.00909)\end{array}$ \\
\hline $\begin{array}{l}\left(\text { Bank Shock }_{f, t}\right)^{*} \\
(\text { Mean Loan-to-Asset Ratio } f)\end{array}$ & $\begin{array}{l}0.148^{* * *} \\
(0.0260)\end{array}$ & $\begin{array}{l}0.147^{* * *} \\
(0.0260)\end{array}$ & $\begin{array}{l}0.145^{* * *} \\
(0.0258)\end{array}$ & $\begin{array}{l}0.146^{* * *} \\
(0.0258)\end{array}$ & $\begin{array}{l}0.147^{* * *} \\
(0.0259)\end{array}$ \\
\hline Firm Shock $f, t$ & $\begin{array}{c}0.137^{* * *} \\
(0.00284)\end{array}$ & $\begin{array}{c}0.133^{* * *} \\
(0.00277)\end{array}$ & $\begin{array}{c}0.135^{* * *} \\
(0.00279)\end{array}$ & $\begin{array}{l}0.138^{* * *} \\
(0.00285)\end{array}$ & $\begin{array}{l}0.143^{* * *} \\
(0.00293)\end{array}$ \\
\hline $\begin{array}{l}\left(\text { Firm Shock }_{f, t}\right)^{*} \\
(\text { Mean Loan-to-Asset Ratio } f)\end{array}$ & $\begin{array}{r}0.143^{* * *} \\
(0.0143)\end{array}$ & $\begin{array}{r}0.143^{* * *} \\
(0.0143)\end{array}$ & $\begin{array}{l}0.141^{* * *} \\
(0.0141)\end{array}$ & $\begin{array}{r}0.142^{* * *} \\
(0.0141)\end{array}$ & $\begin{array}{r}0.142^{* * *} \\
(0.0142)\end{array}$ \\
\hline $\begin{array}{l}\left(\text { Bank Shock }_{f, t}\right)^{*} \\
\Delta(\text { Other-Loan-to-Asset Ratio } f, t)\end{array}$ & $\begin{array}{c}-0.142^{* * *} \\
(0.0413)\end{array}$ & & & & $\begin{array}{r}-0.161^{* * *} \\
(0.0436)\end{array}$ \\
\hline $\begin{array}{l}\left(\text { Bank Shock }_{f, t}\right)^{*} \\
(\text { Other-Loan-to-Asset Ratio } f, t-1)\end{array}$ & $\begin{array}{r}-0.101^{* * *} \\
(0.0388)\end{array}$ & & & & $\begin{array}{r}-0.103^{* * *} \\
(0.0390)\end{array}$ \\
\hline $\begin{array}{l}\left(\text { Bank Shock }_{f, t}\right)^{*} \\
\left.\Delta \text { (Bonds-to-Asset Ratio }_{f, t}\right)\end{array}$ & & $\begin{array}{l}-0.410 \\
(0.511)\end{array}$ & & & \\
\hline $\begin{array}{l}\left(\text { Bank Shock }_{f, t}\right)^{*} \\
(\text { Bonds-to-Asset Ratio } f, t-1)\end{array}$ & & $\begin{array}{c}-0.0931 \\
(0.370)\end{array}$ & & & \\
\hline $\begin{array}{l}\left(\text { Bank Shock }_{f, t}\right)^{*} \\
\Delta\left(\text { Intra-Group-to-Asset Ratio }_{f, t}\right)\end{array}$ & & & $\begin{array}{r}-0.192^{* * *} \\
(0.0515)\end{array}$ & & \\
\hline $\begin{array}{l}\left(\text { Bank Shock }_{f, t}\right)^{*} \\
\text { (Intra-Group-Loan-to-Asset Ratio } f, t-1)\end{array}$ & & & $\begin{array}{r}-0.177^{* * *} \\
(0.0554)\end{array}$ & & \\
\hline $\begin{array}{l}\left(\text { Bank Shock }_{f, t}\right)^{*} \\
\left.\Delta \text { (LTS-to-Asset Ratio }_{f, t}\right)\end{array}$ & & & & $\begin{array}{r}-0.0972^{* *} \\
(0.0444)\end{array}$ & $\begin{array}{r}-0.142^{* * *} \\
(0.0466)\end{array}$ \\
\hline $\begin{array}{l}\left(\text { Bank Shock }_{f, t}\right)^{*} \\
\left.\text { (LTS-to-Asset Ratio }_{f, t-1}\right)\end{array}$ & & & & $\begin{array}{r}-0.0631^{*} \\
(0.0322)\end{array}$ & $\begin{array}{c}-0.0728^{* *} \\
(0.0324)\end{array}$ \\
\hline Industry shock $_{f, t}$ & $\begin{array}{l}0.491^{* * *} \\
(0.0292)\end{array}$ & $\begin{array}{l}0.498^{* * *} \\
(0.0293)\end{array}$ & $\begin{array}{l}0.495^{* * *} \\
(0.0292)\end{array}$ & $\begin{array}{r}0.485^{* * *} \\
(0.0293)\end{array}$ & $\begin{array}{r}0.481^{* * *} \\
(0.0292)\end{array}$ \\
\hline \multicolumn{6}{|l|}{ Fixed Effects } \\
\hline Year & Yes & Yes & Yes & Yes & Yes \\
\hline Firm & Yes & Yes & Yes & Yes & Yes \\
\hline Observations & 656246 & 656246 & 656246 & 656246 & 656246 \\
\hline $\mathrm{R}^{2}$ & 0.389 & 0.388 & 0.389 & 0.389 & 0.389 \\
\hline
\end{tabular}

TABle 6. Firm-Level Investment - Capital Structure - Changes and Lags

Notes: Robust standard errors in parentheses. ${ }^{* *} \mathrm{p}<0.01,{ }^{*} \mathrm{p}<0.05{ }^{*} \mathrm{p}<0.1$. We drop the top and bottom two and a half percentiles of each variable. The Mean Bank-Loan-to-Asset Ratio is defined for each firm as its average ratio of bank loans to assets over the sample period. The main effects of the changes in and lags of the Other-Loan-to-Asset Ratio, Bondsto-Asset Ratio, Intra-Group-Loan-to-Asset Ratio and LTS-to-Asset Ratio are also included in the regression, but omitted in the table due to space constraints. 


\begin{tabular}{|c|c|c|c|c|c|c|}
\hline & (1) & $(2)$ & $(3)$ & (4) & (5) & (6) \\
\hline Dependent Variable: & Full & Full & Full & Full & Full & Full \\
\hline Investment $f, t_{f} /$ Capital $_{f, t-1}$ & Sample & Sample & Sample & Sample & Sample & Sample \\
\hline Cash Flow $f, t /$ Capital $_{f, t-1}$ & $\begin{array}{l}0.0257^{* * *} \\
(0.000404)\end{array}$ & $\begin{array}{l}0.0257^{* * *} \\
(0.000404)\end{array}$ & $\begin{array}{l}0.0258^{* * *} \\
(0.000404)\end{array}$ & $\begin{array}{l}0.0258^{* * *} \\
(0.000404)\end{array}$ & $\begin{array}{l}0.0258^{* * *} \\
(0.000405)\end{array}$ & $\begin{array}{l}0.0258^{* * *} \\
(0.000405)\end{array}$ \\
\hline Sales Growth $f, t-1$ & $\begin{array}{r}0.0295^{* * *} \\
(0.00186)\end{array}$ & $\begin{array}{r}0.0295^{* * *} \\
(0.00186)\end{array}$ & $\begin{array}{r}0.0296^{* * *} \\
(0.00186)\end{array}$ & $\begin{array}{r}0.0296^{* * *} \\
(0.00186)\end{array}$ & $\begin{array}{r}0.0293^{* * *} \\
(0.00186)\end{array}$ & $\begin{array}{r}0.0293^{* * *} \\
(0.00186)\end{array}$ \\
\hline Bank Shock $_{f, t}$ & $\begin{array}{l}0.149^{* * *} \\
(0.00844)\end{array}$ & $\begin{array}{c}0.149^{* * *} \\
(0.00840)\end{array}$ & $\begin{array}{l}0.162^{* * *} \\
(0.00955)\end{array}$ & $\begin{array}{l}0.162^{* * *} \\
(0.00950)\end{array}$ & $\begin{array}{l}0.158^{* * *} \\
(0.00921)\end{array}$ & $\begin{array}{c}0.158^{* * *} \\
(0.00916)\end{array}$ \\
\hline $\begin{array}{l}\left(\text { Bank Shock }_{f, t}\right)^{*} \\
(\text { Mean Bank-Loan-to-Asset Ratio } f)\end{array}$ & $\begin{array}{l}0.147^{* * *} \\
(0.0259)\end{array}$ & $\begin{array}{l}0.146^{* * *} \\
(0.0259)\end{array}$ & $\begin{array}{l}0.150^{* * *} \\
(0.0262)\end{array}$ & $\begin{array}{l}0.150^{* * *} \\
(0.0262)\end{array}$ & $\begin{array}{l}0.147^{* * *} \\
(0.0258)\end{array}$ & $\begin{array}{l}0.146^{* * *} \\
(0.0258)\end{array}$ \\
\hline Firm Shock $_{f, t}$ & $\begin{array}{c}0.134^{* * *} \\
(0.00280)\end{array}$ & $\begin{array}{l}0.135^{* * *} \\
(0.00278)\end{array}$ & $\begin{array}{l}0.144^{* * *} \\
(0.00302)\end{array}$ & $\begin{array}{l}0.144^{* * *} \\
(0.00299)\end{array}$ & $\begin{array}{l}0.145^{* * *} \\
(0.00297)\end{array}$ & $\begin{array}{l}0.145^{* * *} \\
(0.00295)\end{array}$ \\
\hline $\begin{array}{l}\left(\text { Firm Shock }_{f, t}\right)^{*} \\
(\text { Mean Bank-Loan-to-Asset Ratio } f)\end{array}$ & $\begin{array}{l}0.142^{* * *} \\
(0.0142)\end{array}$ & $\begin{array}{l}0.141^{* * *} \\
(0.0142)\end{array}$ & $\begin{array}{l}0.146^{* * *} \\
(0.0144)\end{array}$ & $\begin{array}{l}0.145^{* * *} \\
(0.0144)\end{array}$ & $\begin{array}{l}0.142^{* * *} \\
(0.0141)\end{array}$ & $\begin{array}{c}0.141^{* * *} \\
(0.0141)\end{array}$ \\
\hline$\left(\text { Bank Shock }_{f, t}\right)^{*}\left(\right.$ Employees $\left._{\text {Large }}\right)$ & $\begin{array}{c}-0.0473^{* *} \\
(0.0231)\end{array}$ & & $\begin{array}{c}-0.0565^{* *} \\
(0.0233)\end{array}$ & & $\begin{array}{c}-0.0542^{* *} \\
(0.0232)\end{array}$ & \\
\hline$\left(\right.$ Bank Shock $\left._{f, t}\right) *\left(\right.$ Sales $\left._{\text {Large }}\right)$ & & $\begin{array}{c}-0.0832^{* *} \\
(0.0328)\end{array}$ & & $\begin{array}{c}-0.0929^{* * * *} \\
(0.0330)\end{array}$ & & $\begin{array}{c}-0.0879^{* * *} \\
(0.0328)\end{array}$ \\
\hline$\left(\right.$ Firm Shock $\left._{f, t}\right) *\left(\right.$ Employees $\left._{\text {Large }}\right)$ & $\begin{array}{c}-0.0340^{* * *} \\
(0.00580)\end{array}$ & & $\begin{array}{c}-0.0388^{* * *} \\
(0.00587)\end{array}$ & & $\begin{array}{c}-0.0358^{* * *} \\
(0.00581)\end{array}$ & \\
\hline$\left(\right.$ Firm Shock $\left._{f, t}\right) *\left(\right.$ Sales $\left._{\text {Large }}\right)$ & & $\begin{array}{c}-0.0609^{* * *} \\
(0.00723)\end{array}$ & & $\begin{array}{c}-0.0663^{* * *} \\
(0.00733)\end{array}$ & & $\begin{array}{c}-0.0608^{* * *} \\
(0.00724)\end{array}$ \\
\hline 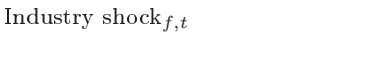 & $\begin{array}{l}0.500^{* * *} \\
(0.0292)\end{array}$ & $\begin{array}{l}0.500^{* * *} \\
(0.0291)\end{array}$ & $\begin{array}{l}0.496^{* * *} \\
(0.0292)\end{array}$ & $\begin{array}{l}0.497^{* * *} \\
(0.0291)\end{array}$ & $\begin{array}{l}0.483^{* * *} \\
(0.0291)\end{array}$ & $\begin{array}{l}0.483^{* * *} \\
(0.0291)\end{array}$ \\
\hline \multicolumn{7}{|l|}{ Controls for Capital Structure } \\
\hline Mean & No & No & Yes & Yes & No & No \\
\hline Lags and Differences & No & No & No & No & Yes & Yes \\
\hline \multicolumn{7}{|l|}{ Fixed Effects } \\
\hline Year & Yes & Yes & Yes & Yes & Yes & Yes \\
\hline Firm & Yes & Yes & Yes & Yes & Yes & Yes \\
\hline Observations & 656246 & 656246 & 656246 & 656246 & 656246 & 656246 \\
\hline $\mathrm{R}^{2}$ & 0.388 & 0.388 & 0.389 & 0.389 & 0.389 & 0.389 \\
\hline
\end{tabular}

TABLe 7. Firm-Level Investment - Firm Size

Notes: Robust standard errors in parentheses. ${ }^{* * *} \mathrm{p}<0.01,{ }^{* *} \mathrm{p}<0.05{ }^{*} \mathrm{p}<0.1$. We drop the top and bottom two and a half percentiles of each variable. The Mean Bank-Loan-to-Asset Ratio is defined for each firm as its average ratio of bank loans to assets over the sample period. The controls for the capital structure in addition include the following variables. Mean: Interaction between the Mean Other-Loan-to-Asset Ratio and Mean LTS-to-Asset Ratio with the Bank Shock and Firm Shock. Lags and Differences: The lag and first difference of the Other-Loan-to-Asset Ratio and the LTS-to-Asset Ratio interacted with the Bank Shock and Firm Shock as well as their main effect.

less than small firms when their banks get hit by a credit supply shock of the same magnitude. The same finding holds true for the interaction of the firm shock with firm size. Large firms usually have a more diversified capital structure than small firms, which may explain why they are less affected by adverse bank shocks given our results from the previous paragraphs. Therefore, in Column 3 and Column 4 we control for the mean other-loan-to-asset ratio and the mean sharehold-debt-to-asset ratio, and in Column 5 and Column 6 we 
include lags and first differences of the two variables as controls instead. We find that the coefficients of the interaction between bank and firm shocks with firm size does not change appreciably when controlling for the capital structure of firms. In Section 4.3 we documented that the firm-borrowing channel of larger firms is usually more positive than for smaller firms. This resulted from longer maturities of their loans, differential treatment of firms by their banks and substitution of borrowing towards less affected banks. All three factors contribute to a more favourable credit supply for large firms, which shields their investments from adverse credit supply shocks to a certain extent.

\subsection{Bank Shocks and Aggregate Lending and Investment}

One important feature of the methodology proposed by AW is that it also provides a complete decomposition of loan growth rates into bank, firm, industry and common shocks at the aggregate level. Figure 5a presents the aggregate decomposition results for our quarterly dataset between 2005 and 2014. ${ }^{18}$ The aggregate bank shock series is characterised by two pronounced contractions during which its values fall below zero indicating that larger banks in Portugal were particularly hard hit by idiosyncratic shocks in the last decade. The two aggregate credit supply squeezes correspond to the outbreak of the unexpected freeze of the European interbank market (Iyer et al. 2014) as well as the onset and peak of the sovereign debt crisis in Europe with its concurrent effects on bank lending (Popov and van Horen 2013). In the most recent period supply side factors are beginning to show a recovery. The variation in the aggregate firm shock series is much lower and overall larger firms appear to have faced more benevolent conditions than smaller firms. However, since 2008 firm-specific factors have progressively decreased loan growth in the aggregate interrupted only by a brief recovery in 2010 .

In the following we assess whether the four shocks are important for explaining aggregate loan and investment dynamics. First, we consider a regression of the aggregate bank, firm, industry and common shock on the growth rate of total loans to the private sector (Column 1 of Table 8). All coefficients are statistically indistinguishable from one, which is what one would expect since the four shocks provide a complete decomposition of the aggregate loan growth rate in the credit registry database and given that the latter has very similar dynamics to the loan growth rate of the private sector as a whole (Figure 1a). Column 2 presents the results of the same regression with standardised variables so that the coefficients of the shocks can be interpreted in terms of standard deviations. Therefore, a one standard deviation increase in the aggregate bank shock series leads to an increase of the aggregate loan

18. We use quarterly instead of annual data and also include the year 2014 in this section since we require a dataset with a larger number of observations in order to perform the subsequent econometric analysis. 
growth rate by 0.66 standard deviations. The common shock as well as the aggregate firm shock also have sizeable effects on loan developments in the private sector while the industry shock appears to be of minor importance. Column 3 and Column 4 present the corresponding results for a regression on net investment, which is defined analogously to the measure used for the firm-level analysis. We find that the coefficients of the common shock as well as the aggregate firm and bank shock are highly significant. Column 5 and Column 6 present the regression results for the growth rate of private investment excluding housing, which is a measure of investment more typically used in macroeconomic analysis (Figure 5b). The aggregate firm and bank shock both remain highly significant for this alternative investment series. Overall, this highlights that granular shocks in the banking system have a palpable impact on aggregate investment dynamics in the Portuguese economy.

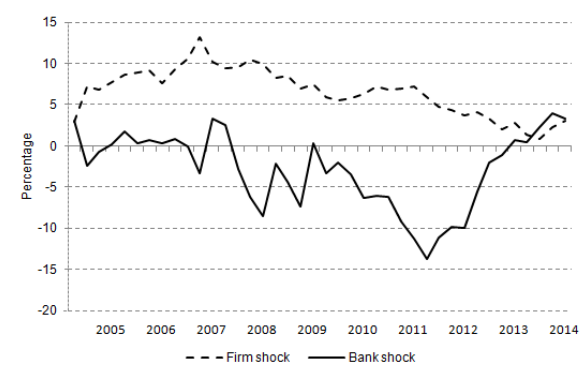

(A) Aggregate Bank and Firm Shock

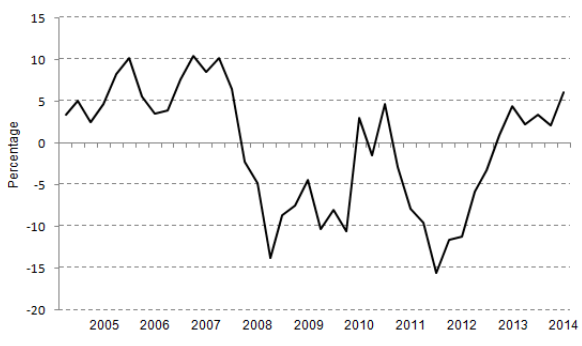

(в) Growth of Private Investment Excl. Housing

Figure 5: Aggregate Shocks and Growth Rate of Private Investment Excluding Housing

In order to gauge the quantitative importance of the four shocks in explaining aggregate loan and investment dynamics, we perform an $R^{2}$ decomposition of the regressions above. If all regressors were uncorrelated, their importance would just be the $R^{2}$-increase when adding a particular variable to any subset of regressors and their contributions would add up to the $R^{2}$ of the full model. However, since the regressors are correlated it is no longer straightforward to break down the $R^{2}$ of the full model into contributions from individual regressors. In the following we use two different statistical procedures, which take the dependence on the order of introducing variables in the regression into account. This is implemented either by averaging over different sequences using simple unweighted averages (LMG) as first proposed by Lindeman et al. (1980) or alternatively by using weighted averages 
with data-dependent weights (PMVD for proportional marginal variance decomposition) as suggested by Feldman (2005). ${ }^{19}$

The lower panel of Table 8 presents the results of these two $R^{2}$ decomposition methods for the three sets of regressions above. In the regression on total loan growth (Column 1 and Column 2) the most important factors are common and firm shocks, which account for around 35 to 38 and 39 to 40 percent of the aggregate dynamics, respectively. About 15 to 20 percent of the variation in aggregate loan growth is due to granular shocks in the Portuguese banking system. A similar result holds for the corresponding $R^{2}$ decomposition of the regression on the investment to capital ratio (Column 3 and Column 4). Here, granular bank shocks explain around 18 to 24 percent of the variation in the data, while about one third each derives from shocks affecting all lending-borrowing relationships and firm-specific shocks. Alternatively, when considering the growth rate of investment, which is more commonly used in macroeconomics, we find that the aggregate bank shock accounts for 37 to 38 percent of its dynamics, while in this case the common shock and the aggregate firm shock are much less important (Column 5 and Column 6). Overall, the contributions deriving from granular bank shocks in Portugal appear to be a little lower than for the Japanese sample studied by AW, in which case the aggregate bank shock explained about 36 and 37 percent of the variation in loan growth and net investment. Partially, this may be due to differences in the frequencies of the series under consideration - quarterly versus annual - in case granular bank shocks are more important in explaining medium-term movements of aggregate variables. Methodological considerations aside this suggests that economy-wide factors along with firm-specific shocks may have played a slightly larger role in Portugal in the past decade than in Japan. However, on the whole our analysis provides strong evidence for the importance of granular bank shocks in explaining aggregate fluctuations and supports the findings by AW for the Japanese economy.

19. All decompositions were performed using the $R$ package relaimpo (Groemping 2006). 


\begin{tabular}{|c|c|c|c|c|c|c|}
\hline \multirow[t]{2}{*}{ Dependent Variable: } & \multicolumn{2}{|c|}{ Loan Growth $t$} & \multicolumn{2}{|c|}{${\text { Investment } t / \text { Capital }_{t-1}}$} & \multicolumn{2}{|c|}{$\begin{array}{l}\text { Growth Rate of Private } \\
\text { Investment Excl. Housing }\end{array}$} \\
\hline & (1) & $(2)$ & $(3)$ & $(4)$ & $(5)$ & $(6)$ \\
\hline Common Shock $_{t}$ & $\begin{array}{c}1.158^{* * *} \\
(0.124\end{array}$ & $\begin{array}{c}0.715^{* * *} \\
(0.077)\end{array}$ & $\begin{array}{c}0.527^{* * *} \\
(0.048)\end{array}$ & $\begin{array}{c}0.742^{* * *} \\
(0.067)\end{array}$ & $\begin{array}{l}-0.107 \\
(0.321)\end{array}$ & $\begin{array}{l}-0.044 \\
(0.132)\end{array}$ \\
\hline Industry $\mathrm{Shock}_{t}$ & $\begin{array}{c}0.597 \\
(0.690)\end{array}$ & $\begin{array}{c}0.053 \\
(0.061)\end{array}$ & $\begin{array}{l}0.0282 \\
(0.269)\end{array}$ & $\begin{array}{c}0.057 \\
(0.054)\end{array}$ & $\begin{array}{l}4.521^{*} \\
(2.586)\end{array}$ & $\begin{array}{l}0.265^{*} \\
(0.151)\end{array}$ \\
\hline Firm Shock $t$ & $\begin{array}{c}0.944^{* * *} \\
(0.146)\end{array}$ & $\begin{array}{c}0.481^{* * *} \\
(0.074)\end{array}$ & $\begin{array}{c}0.381^{* * *} \\
(0.046)\end{array}$ & $\begin{array}{c}0.440^{* * *} \\
(0.053)\end{array}$ & $\begin{array}{c}1.257^{* * *} \\
(0.304)\end{array}$ & $\begin{array}{c}0.426^{* * *} \\
(0.103)\end{array}$ \\
\hline Bank Shock $_{t}$ & $\begin{array}{c}0.914^{* * *} \\
(0.101)\end{array}$ & $\begin{array}{c}0.665^{* * *} \\
(0.074)\end{array}$ & $\begin{array}{c}0.434^{* * *} \\
(0.033)\end{array}$ & $\begin{array}{c}0.720^{* * *} \\
(0.054)\end{array}$ & $\begin{array}{c}1.736^{* * *} \\
(0.275)\end{array}$ & $\begin{array}{c}0.840^{* * *} \\
(0.133)\end{array}$ \\
\hline Constant & $\begin{array}{l}-0.022^{*} \\
(0.011)\end{array}$ & $\begin{array}{c}0.000 \\
(0.040)\end{array}$ & $\begin{array}{c}0.018^{* * *} \\
(0.005)\end{array}$ & $\begin{array}{c}0.000 \\
(0.042)\end{array}$ & $\begin{array}{c}-0.087^{* * *} \\
(0.028)\end{array}$ & $\begin{array}{c}0.000 \\
(0.112)\end{array}$ \\
\hline Standardised Variables & No & Yes & No & Yes & No & Yes \\
\hline Observations & 40 & 40 & 40 & 40 & 40 & 40 \\
\hline$R^{2}$ & 0.943 & 0.943 & 0.938 & 0.938 & 0.547 & 0.547 \\
\hline$\%$ of $T S S$ & LMG & PMVD & LMG & PMVD & LMG & PMVD \\
\hline Common Shock $_{t}$ & 0.376 & 0.352 & 0.371 & 0.378 & 0.033 & 0.001 \\
\hline Industry Shock $t$ & 0.019 & 0.002 & 0.023 & 0.002 & 0.045 & 0.042 \\
\hline Firm Shock $t$ & 0.401 & 0.388 & 0.368 & 0.322 & 0.104 & 0.122 \\
\hline Bank Shock $_{t}$ & 0.146 & 0.200 & 0.175 & 0.235 & 0.365 & 0.382 \\
\hline
\end{tabular}

TABLE 8. Aggregate Effects

Notes: Robust standard errors in parentheses. ${ }^{* * *} \mathrm{p}<0.01,{ }^{* *} \mathrm{p}<0.05{ }^{*} \mathrm{p}<0.1$. The sample corresponds to the period 2005Q1 to 2014Q4. TSS refers to the total sum of squares of the regressions. LMG details the contributions of individual regressors based on simple unweighted averages (Lindeman et al. 1980). PMVD stands for proportional marginal variance decomposition which computes contributions of individual regressors using weighted averages with data-dependent weights (Feldman 2005).

\section{Conclusion}

In this paper, we show that bank shocks have a sizeable impact on both firmlevel as well as aggregate investment in the Portuguese economy. We do this by applying the decomposition framework proposed by AW to a rich dataset of matched bank-firm loans comprising close to 200,000 firms. In comparison to a simple fixed-effects approach the introduction of an adding-up constraint in the methodology by AW has the advantage of being much more efficient and providing macro-level estimates of bank shocks that are consistent with the micro-level shock decomposition. While AW consider a sample of large Japanese firms with multiple bank relationships, we argue that their methodology can also be applied to datasets including small firms with few banking relationships, as long as they represent a small share of the total loan volume of their banks. This insight considerably widens the applicability of the methodology by AW since in most countries the population of firms contains a large share of small 
firms with few banking relationships due to the right-skewed nature of the firm size distribution (Axtell 2001; Cabral and Mata 2003; Khwaja and Mian 2008).

We estimate bank-lending shocks, firm-borrowing shocks, industry-level shocks as well as common shocks using a matched bank-firm loan dataset for the Portuguese economy for the time period 2005 to 2013. We show that bank supply shocks have a strong and robust effect on firm-level investment for the average firm in our sample. The broad coverage of firms in our microdataset provides strong support for the findings by AW and makes it possible to consider how the effect of credit supply shocks varies across firms with different characteristics. Small firms are found to be much more vulnerable to the adverse impact of bank shocks on investment mainly for two reasons. First, their bank lending contracts much more than for large firms since they are less able to substitute their borrowing from other banks. Moreover, they have a larger share of short-term maturities and they may be considered more risky by their banks than larger firms. Second, while we find that alternative financing sources mitigate the adverse impact of bank shocks on investment, small firms are almost entirely bank-dependent and hence feel the full brunt of disruptions to their banks' credit supply.

The banking system in Portugal - as in most other countries - is very concentrated. The ten largest banks account for more than three quarters of the total loan volume in our dataset. This implies that idiosyncratic shocks to these institutions do not average out in the aggregate, but can have a considerable effect on total lending and hence investment. We find that granular bank shocks account for around 20 percent of aggregate loan growth and 20 to 40 percent of aggregate investment dynamics in the Portuguese economy at a quarterly frequency. The values are slightly lower than for the Japanese sample studied by AW, which suggests that economy-wide factors along with firm-specific shocks may have played a slightly larger role in Portugal in the past decade than in Japan. However, on the whole our analysis provides strong evidence for the importance of granular bank shocks in explaining aggregate fluctuations. Looking to the future, quantifying the relative roles of bank shocks and common shocks using data for other economies and episodes is a promising area for future research. 


\section{References}

Adrian, Tobias, Paolo Colla, and Hyun Song Shin (2012). Which Financial Frictions? Parsing the Evidence from the Financial Crisis of 2007 to 2009, pp. 159-214. University of Chicago Press.

Albertazzi, Ugo and Domenico J. Marchetti (2010). "Credit Supply, Flight to Quality and Evergreening: An Analysis of Bank-Firm Relationships after Lehman." Temi di discussione (Economic working papers) 756, Bank of Italy, Economic Research and International Relations Area.

Amador, João and Ana Cristina Soares (2014). "Competition in the Portuguese Economy: Estimated Price-Cost Margins under Imperfect Labour Markets." Working Paper Series 1751, European Central Bank.

Amiti, Mary and David E. Weinstein (2011). "Exports and Financial Shocks." The Quarterly Journal of Economics, 126(4), 1841-1877.

Amiti, Mary and David E. Weinstein (2013). "How Much do Bank Shocks Affect Investment? Evidence from Matched Bank-Firm Loan Data." NBER Working Papers 18890, National Bureau of Economic Research, Inc.

Ashcraft, Adam B. (2005). "Are Banks Really Special? New Evidence from the FDIC-Induced Failure of Healthy Banks." American Economic Review, 95(5), 1712-1730.

Axtell, Robert L. (2001). "Zipf Distribution of U.S. Firm Sizes." Science, 293(5536), 1818-1820.

Barclay, Michael J. and Clifford W. Smith (1995). "The Maturity Structure of Corporate Debt." The Journal of Finance, 50(2), 609-631.

Beck, Thorsten, Asli Demiguc-Kunt, Luc Laeven, and Ross Levine (2008). "Finance, Firm Size, and Growth." Journal of Money, Credit and Banking, 40(7), 1379-1405.

Bernanke, Ben S. and Mark Gertler (1995). "Inside the Black Box: The Credit Channel of Monetary Policy Transmission." Journal of Economic Perspectives, 9(4), 27-48.

Binks, M. R., C. T. Ennew, and G. V. Reed (1992). "Information Asymmetries and the Provision of Finance to Small Firms." International Small Business Journal, 11(1), 35-46.

Bloom, Nick, Stephen Bond, and John Van Reenen (2007). "Uncertainty and Investment Dynamics." The Review of Economic Studies, 74(2), 391-415.

Bremus, Franziska, Claudia Buch, Katheryn Russ, and Monika Schnitzer (2013). "Big Banks and Macroeconomic Outcomes: Theory and CrossCountry Evidence of Granularity." Working Paper 19093, National Bureau of Economic Research.

Buera, Francisco J., Roberto Fattal-Jaef, and Yongseok Shin (2014). "Anatomy of a Credit Crunch: From Capital to Labor Markets." Working Paper 1997, National Bureau of Economic Research.

Cabral, Luís M. B. and José Mata (2003). "On the Evolution of the Firm Size Distribution: Facts and Theory." The American Economic Review, 93(4), pp. 
$1075-1090$.

Chava, Sudheer and Amiyatosh Purnanandam (2011). "The Effect of Banking Crisis on Bank-Dependent Borrowers." Journal of Financial Economics, 99(1), $116-135$.

Chodorow-Reich, Gabriel (2014). "The Employment Effects of Credit Market Disruptions: Firm-level Evidence from the 2008-9 Financial Crisis." The Quarterly Journal of Economics, 129(1), 1-59.

den Heuvel, Skander J. Van (2008). "The Welfare Cost of Bank Capital Requirements." Journal of Monetary Economics, 55(2), 298 - 320.

Desai, Mihir A., C. Fritz Foley, and Kristin J. Forbes (2008). "Financial Constraints and Growth: Multinational and Local Firm Responses to Currency Depreciations." Review of Financial Studies, 21(6), 2857-2888.

Devereux, Michael B. and Alan Sutherland (2011). "Evaluating International Financial Integration under Leverage Constraints." European Economic Review, 55(3), $427-442$.

di Giovanni, Julian, Andrei A. Levchenko, and Isabelle Mejean (2014). "Firms, Destinations, and Aggregate Fluctuations." Econometrica, 82(4), 1303-1340.

Diamond, Douglas W. (1991). "Debt Maturity Structure and Liquidity Risk." The Quarterly Journal of Economics, 106(3), pp. 709-737.

Dwenger, Nadja, Frank M. Fossen, and Martin Simmler (2015). "From Financial to Real Economic Crisis: Evidence from Individual Firm-Bank Relationships in Germany." Discussion Papers of DIW Berlin 1510, DIW Berlin, German Institute for Economic Research.

European Central Bank (2014). Monthly Bulletin April, European Central Bank.

Feldman, B. (2005). "Relative Importance and Value." Mimeo.

Gabaix, Xavier (2011). "The Granular Origins of Aggregate Fluctuations." Econometrica, 79(3), 733-772.

Gerali, Andrea, Stefano Neri, Luca Sessa, and Federico M. Signoretti (2010). "Credit and Banking in a DSGE Model of the Euro Area." Journal of Money, Credit and Banking, 42, 107-141.

Groemping, Ulrike (2006). "Relative Importance for Linear Regression in R: The Package relaimpo." Journal of Statistical Software, 17(1), 1-27.

Hosono, Kaoru and Daisuke Miyakawa (2015). "Bank Lending and Firm Activities: Overcoming Identification Problems." In The Economics of Interfirm Networks, Advances in Japanese Business and Economics, vol. 4, edited by Tsutomu Watanabe, Iichiro Uesugi, and Arito Ono, pp. 237-260. Springer Japan.

Iyer, Rajkamal, José-Luis Peydró, Samuel da Rocha-Lopes, and Antoinette Schoar (2014). "Interbank Liquidity Crunch and the Firm Credit Crunch: Evidence from the 2007-2009 Crisis." Review of Financial Studies, 27(1), $347-372$.

Jimenez, Gabriel, Steven Ongena, Jose-Luis Peydro, and Jesus Saurina (2012). "Credit Supply and Monetary Policy: Identifying the Bank Balance-Sheet 
Channel with Loan Applications." American Economic Review, 102(5), 230126.

Kaoru, Hosono, Miyakawa Daisuke, Uchino Taisuke, Hazama Makoto, Ono Arito, Uchida Hirofumi, and Uesugi Iichiro (2015). "Natural Disasters, Damage to Banks, and Firm Investment." International Economic Review, forthcoming.

Kennedy, Peter (1986). "Interpreting Dummy Variables." The Review of Economics and Statistics, 68(1), 174-75.

Khwaja, Asim Ijaz and Atif Mian (2008). "Tracing the Impact of Bank Liquidity Shocks: Evidence from an Emerging Market." American Economic Review, 98(4), 1413-42.

Kim, Moshe, Doron Kliger, and Bent Vale (2003). "Estimating Switching Costs: The Case of Banking." Journal of Financial Intermediation, 12(1), 25 - 56.

Klein, Michael W., Joe Peek, and Eric S. Rosengren (2002). "Troubled Banks, Impaired Foreign Direct Investment: The Role of Relative Access to Credit." American Economic Review, 92(3), 664-682.

Kollmann, Robert (2013). "Global Banks, Financial Shocks, and International Business Cycles: Evidence from an Estimated Model." Journal of Money, Credit and Banking, 45(s2), 159-195.

Kollmann, Robert, Zeno Enders, and Gernot J. Müller (2011). "Global Banking and International Business Cycles." European Economic Review, 55(3), 407 -426 .

Lindeman, R. H., P. F. Merenda, and R. Z. Gold (1980). Introduction to Bivariate and Multivariate Analysis. Scott Foresman, Glenview, IL.

Miyakawa, Daisuke, Kaoru Hosono, Taisuke Uchino, Arito Ono, Hirofumi Uchida, and Ichiro Uesugi (2015). "Financial Shocks and Firm Exports: A Natural Experiment Approach with a Massive Earthquake." Mo.Fi.R. Working Papers 111, Money and Finance Research group (Mo.Fi.R.) - Univ. Politecnica Marche - Dept. Economic and Social Sciences.

Montgomery, Heather and Satoshi Shimizutani (2009). "The Effectiveness of Bank Recapitalization Policies in Japan." Japan and the World Economy, 21(1), 1 - 25 .

Paravisini, Daniel, Veronica Rappoport, Philipp Schnabl, and Daniel Wolfenzon (2015). "Dissecting the Effect of Credit Supply on Trade: Evidence from Matched Credit-Export Data." The Review of Economic Studies, 82(1), 333359.

Peek, Joe and Eric S. Rosengren (1997). "The International Transmission of Financial Shocks: The Case of Japan." The American Economic Review, $87(4)$, pp. $495-505$.

Peek, Joe and Eric S. Rosengren (2000). "Collateral Damage: Effects of the Japanese Bank Crisis on Real Activity in the United States." American Economic Review, 90(1), 30-45.

Peek, Joe and Eric S. Rosengren (2005). "Unnatural Selection: Perverse Incentives and the Misallocation of Credit in Japan." American Economic 
Review, 95(4), 1144-1166.

Popov, Alexander and Neeltje van Horen (2013). "The Impact of Sovereign Debt Exposure on Bank Lending: Evidence from the European Debt Crisis." DNB Working Papers 382, Netherlands Central Bank, Research Department. Romano, Claudio A, George A Tanewski, and Kosmas X Smyrnios (2001). "Capital Structure Decision Making: A Model for Family Business." Journal of Business Venturing, 16(3), 285 - 310.

Rosengren, Eric S. and Joe Peek (2000). "Collateral Damage: Effects of the Japanese Bank Crisis on Real Activity in the United States." American Economic Review, 90(1), 30-45.

Schnabl, Philipp (2012). "The International Transmission of Bank Liquidity Shocks: Evidence from an Emerging Market." The Journal of Finance, 67(3), 897-932.

Sharpe, Steven A. (1994). "Financial Market Imperfections, Firm Leverage, and the Cyclicality of Employment." The American Economic Review, 84(4), pp. 1060-1074.

Stohs, Mark Hoven and David C. Mauer (1996). "The Determinants of Corporate Debt Maturity Structure." The Journal of Business, 69(3), pp. 279-312.

Suits, Daniel B. (1984). "Dummy Variables: Mechanics V. Interpretation." The Review of Economics and Statistics, 66(1), pp. 177-180.

Task Force of the Monetary Policy Committee of the ESCB (2015). "Savings and Investment Behaviour in the Euro Area." Occasional Paper Series forthcoming, European Central Bank.

Whited, Toni M. (2006). "External Finance Constraints and the Intertemporal Pattern of Intermittent Investment." Journal of Financial Economics, 81(3), $467-502$. 


\section{Appendix}

\section{A.1. Solving the System of Linear Equations}

As discussed in the main text one additional constraint needs to be imposed in order to solve the system of linear equations. We set $\alpha_{1 t}=0$ and express all equations using matrix algebra:

$$
\begin{gathered}
\boldsymbol{A}_{\boldsymbol{t}}^{-} \equiv\left(\begin{array}{c}
\alpha_{2 t} \\
\vdots \\
\alpha_{F t}
\end{array}\right), \boldsymbol{B}_{\boldsymbol{t}} \equiv\left(\begin{array}{c}
\beta_{1 t} \\
\vdots \\
\beta_{B t}
\end{array}\right), \boldsymbol{D}_{\boldsymbol{t}}^{\boldsymbol{F}} \equiv\left(\begin{array}{c}
D_{1 t}^{F} \\
\vdots \\
D_{F t}^{F}
\end{array}\right), \boldsymbol{D}_{\boldsymbol{t}}^{\boldsymbol{B}} \equiv\left(\begin{array}{c}
D_{1 t}^{B} \\
\vdots \\
D_{B t}^{B}
\end{array}\right), \\
\boldsymbol{\Theta}_{\boldsymbol{t}} \equiv\left(\begin{array}{ccc}
\theta_{11 t} & \ldots & \theta_{1 B t} \\
\vdots & \ddots & \vdots \\
\theta_{F 1 t} & \ldots & \theta_{F B t}
\end{array}\right), \boldsymbol{\Phi}_{\boldsymbol{t}}^{-} \equiv\left(\begin{array}{cccc}
\varphi_{21 t} & \ldots & \varphi_{F 1 t} \\
\vdots & \ddots & \vdots \\
\varphi_{2 B t} & \ldots & \varphi_{F B t}
\end{array}\right), \\
\boldsymbol{I}_{\boldsymbol{F}}^{-} \equiv\left(\begin{array}{cccc}
0 & 0 & \ldots & 0 \\
1 & 0 & \ldots & 0 \\
0 & 1 & \ldots & 0 \\
\vdots & \vdots & \ddots & \vdots \\
0 & 0 & \ldots & 1
\end{array}\right),
\end{gathered}
$$

where $\boldsymbol{I}_{\boldsymbol{F}}^{-}$is the $F \times(F-1)$ matrix obtained from deleting the first column of a $F \times F$ identity matrix. In order to solve for the unknown bank and firm shocks we combine bank and firm-level variables as follows

$$
X_{t} \equiv\left(\begin{array}{c}
A_{t}^{-} \\
B_{t}
\end{array}\right), D_{t} \equiv\left(\begin{array}{c}
D_{t}^{F} \\
D_{t}^{B}
\end{array}\right), \Gamma_{t} \equiv\left(\begin{array}{cc}
I_{F}^{-} & \Theta_{t} \\
\Phi_{t}^{-} & I_{B}
\end{array}\right)
$$

where $\boldsymbol{X}_{\boldsymbol{t}}$ is the $(F+B-1) \times 1$ vector collecting unknown firm and bank shocks except $\alpha_{1 t}$ which was set to zero, $\boldsymbol{D}_{\boldsymbol{t}}$ is the $(F+B) \times 1$ vector including the loan growth rates of all firms and banks, and $\boldsymbol{\Gamma}_{\boldsymbol{t}}$ is the $(F+B) \times(F+B-1)$ matrix collecting all the bank and firm weights except those related to $\alpha_{1 t}$. The above definitions allow us to write the system of equations compactly as

$$
\Gamma_{t} X_{t}=D_{t}
$$

In this particular case, we cannot solve the equation by pre-multiplying by the inverse of $\boldsymbol{\Gamma}_{\boldsymbol{t}}$, since $\boldsymbol{\Gamma}_{\boldsymbol{t}}$ is not a square matrix. However, the system is readily solved by any linear equation solver implemented in standard statistical packages or alternatively by pre-multiplying with the Moore-Penrose pseudoinverse $\boldsymbol{\Gamma}_{t}^{+}$

$$
X_{t}=\Gamma_{t}^{+} D_{t}
$$

Our exposition of the estimation methodology differs slightly from the one in AW who express all equations related to the loan growth rates of firms 
relative to firm number one and all equations related to the loan growth rates of banks relative to bank number one. While their approach yields identical results to ours, our presentation emphasises that there is nothing special about this problem and that the imposition of a single constraints (such as $\alpha_{1 t}=0$ ) is sufficient to solve the system of linear equations. Regarding implementation, generating a matrix of size $(F+B) \times(F+B-1)$ may pose a problem on some computer systems if the firm and/or bank dimension is very large and sparse matrix coding is not available. In these situations the algorithm proposed by AW provides a nifty workaround since it only requires memory allocation for matrices of size $(F-1) \times(B-1)$. 


\section{A.2. Normalisation of Bank and Firm Shocks}

The firm and bank shocks derived using the methodology outlined in the previous section are all expressed relative to $\alpha_{1 t}$, i.e. the credit demand shock of firm 1 . Since this is an arbitrary reference point which complicates economic interpretation, we re-express all shocks relative to the median firm shock, $\bar{A}_{t}$, and the median bank shock, $\bar{B}_{t}$. Define the vector $\boldsymbol{A}_{\boldsymbol{t}}$ with the full set of firm shocks and the matrix $\boldsymbol{\Phi}_{t}$ with the full set of bank-lending weights as

$$
\boldsymbol{A}_{\boldsymbol{t}} \equiv\left(\begin{array}{c}
\alpha_{1 t} \\
\vdots \\
\alpha_{F t}
\end{array}\right), \boldsymbol{\Phi}_{\boldsymbol{t}} \equiv\left(\begin{array}{ccc}
\varphi_{11 t} & \ldots & \varphi_{F 1 t} \\
\vdots & \ddots & \vdots \\
\varphi_{1 B t} & \ldots & \varphi_{F B t}
\end{array}\right)
$$

and re-express the firm-borrowing shock as the difference between the actual shock and the median shock $\dot{A}_{t} \equiv \boldsymbol{A}_{t}-\bar{A}_{t} \boldsymbol{\iota}_{\boldsymbol{F}}$, and similarly the bank-lending shock as the actual shock less the median shock, $\dot{\boldsymbol{B}}_{\boldsymbol{t}} \equiv \boldsymbol{B}_{\boldsymbol{t}}-\bar{B}_{t} \iota_{\boldsymbol{B}}$. This allows us to rewrite Equation 4 as

$$
\begin{aligned}
\boldsymbol{D}_{t}^{B} & =\boldsymbol{B}_{\boldsymbol{t}}+\boldsymbol{\Phi}_{t-1} \boldsymbol{A}_{t} \\
& =\dot{B}_{\boldsymbol{t}}+\bar{B}_{t} \iota_{B}+\boldsymbol{\Phi}_{t-1} \dot{A}_{t}+\bar{A}_{t} \boldsymbol{\Phi}_{t-1} \iota_{\boldsymbol{F}} \\
& =\dot{\boldsymbol{B}}_{\boldsymbol{t}}+\boldsymbol{\Phi}_{t-1} \dot{A}_{t}+\left(\bar{A}_{t}+\bar{B}_{t}\right) \iota_{\boldsymbol{B}},
\end{aligned}
$$

and similarly Equation 5 as

$$
\begin{aligned}
D_{t}^{F} & =A_{t}+\Theta_{t-1} B_{t} \\
& =\dot{A}_{t}+\bar{A}_{t} \iota_{F}+\Theta_{t-1} \dot{B}_{t}+\bar{B}_{t} \Theta_{t-1} \iota_{B} \\
& =\dot{A}_{t}+\Theta_{t-1} \dot{B}_{t}+\left(\bar{A}_{t}+\bar{B}_{t}\right) \iota_{F} .
\end{aligned}
$$

In order to isolate industry shocks we define $\tilde{A}_{t} \equiv \dot{A}_{t}-$ median $_{f \in n}\left(\dot{A}_{t}\right)$, where firm $f$ is part of industry $n$. Similarly, define bank shocks relative to the median, but note that $\tilde{\boldsymbol{B}}_{\boldsymbol{t}} \equiv \dot{\boldsymbol{B}}_{\boldsymbol{t}}-\operatorname{median}\left(\dot{\boldsymbol{B}}_{\boldsymbol{t}}\right)=\dot{\boldsymbol{B}}_{\boldsymbol{t}}$ since median $\left(\dot{\boldsymbol{B}}_{\boldsymbol{t}}\right)=0$. Finally, we define the $F \times 1$ vector of industry medians $\boldsymbol{N}_{\boldsymbol{t}}$ corresponding to the $F$ firms in the sample, which allows us to arrive at the firm and bank decompositions used in the main text

$$
D_{t}^{F}=\tilde{A}_{t}+N_{t}+\Theta_{t-1} \tilde{B}_{t}+\left(\bar{A}_{t}+\bar{B}_{t}\right) \iota_{F},
$$

and

$$
D_{t}^{B}=\tilde{B}_{t}+\Phi_{t-1} \tilde{A}_{t}+\Phi_{t-1} N_{t}+\left(\bar{A}_{t}+\bar{B}_{t}\right) \iota_{B}
$$




\section{A.3. Additional Results}

\begin{tabular}{|c|c|c|c|c|}
\hline Dependent Variable: Bank Shock ${ }_{b, t}$ & (1) & (2) & (3) & (4) \\
\hline Low Capital Adequacy Ratio $b, t$ & $\begin{array}{c}-0.0639^{* *} \\
(0.0257)\end{array}$ & & & \\
\hline Large Capital Increase $b, t$ & & $\begin{array}{c}0.0421^{* *} \\
(0.0214)\end{array}$ & & \\
\hline Low Return on Assets $_{b, t}$ & & & $\begin{array}{c}-0.126^{* * *} \\
(0.0295)\end{array}$ & \\
\hline Low Return on Equity $b, t$ & & & & $\begin{array}{c}-0.0770^{* * *} \\
(0.0258) \\
\end{array}$ \\
\hline Year fixed effects & Yes & Yes & Yes & Yes \\
\hline Observations & 997 & 1314 & 1128 & 1128 \\
\hline $\mathrm{R}^{2}$ & .011 & .012 & .019 & .011 \\
\hline
\end{tabular}

TABle A.1. Validation of Bank-Supply Shocks - Robustness

Notes: Robust standard errors in parentheses. ${ }^{* * *} \mathrm{p}<0.01,{ }^{* *} \mathrm{p}<0.05{ }^{*} \mathrm{p}<0.1$. We drop the top and bottom two and a half percentiles of bank supply shocks. The capital adequacy ratio is the combined Tier 1 and Tier 2 capital divided by the banks' risk weighted assets. The regressor in Column 1 is a dummy variable equal to 1 if bank $b$ 's capital adequacy ratio is in the lowest decile of our sample (smaller than 9.07 percent). Capital increases are defined as the growth rate of Tier 1 capital. In Column 2 the regressor is a dummy variable that takes the value 1 if the capital increase of bank $b$ is in the top decile of our sample (larger than 23.9 percent). Return on assets is defined as the net income of bank $b$ over its average total assets. In Column 3 the regressor is a dummy variable which equals 1 if a bank's return on assets is in the bottom decile (smaller than -1.2 percent). Return on equity is defined as the net income of bank $b$ over its net assets. The regressor in Column 4 the regressor is a dummy variable which equals 1 if a bank's return on equity is in the bottom decile (smaller than -8.6 percent). All information was taken from bank-level regulatory data collected by Banco de Portugal. 


\section{A.4. Summary Statistics}

\begin{tabular}{|c|c|c|c|c|c|}
\hline By Year & Mean & SD & 1st quartile & Median & 3rd quartile \\
\hline Percent Change in Flow-of-Funds $t$ & 0.019 & 0.062 & -0.051 & 0.018 & 0.066 \\
\hline Investment $_{t} /$ Capital $_{t-1}$ & 0.034 & 0.027 & 0.006 & 0.035 & 0.060 \\
\hline Percent Change of Private Investment $t$ & -0.008 & 0.093 & -0.098 & 0.019 & 0.060 \\
\hline Common Shock $_{t}$ & -0.001 & 0.038 & -0.020 & 0.003 & 0.016 \\
\hline \multicolumn{6}{|l|}{ By Bank } \\
\hline Bank Shock $_{b, t}$ & 0.032 & 0.288 & -0.130 & 0.000 & 0.158 \\
\hline Capital Adequacy Ratio $b, t$ & 0.282 & 0.618 & 0.116 & 0.156 & 0.236 \\
\hline Growth Rate of Tier 1 Capital $_{b, t}$ & 0.057 & 0.420 & -0.003 & 0.042 & 0.111 \\
\hline Return on Assets $_{b, t}$ & -0.000 & 0.067 & 0.000 & 0.004 & 0.009 \\
\hline Return on Equity $b, t$ & 0.065 & 2.769 & 0.010 & 0.050 & 0.119 \\
\hline \multicolumn{6}{|l|}{ By Firm } \\
\hline Investment $_{f, t} /$ Capital $_{f, t-1}$ & -0.051 & 0.396 & -0.237 & -0.084 & 0.000 \\
\hline Cash Flow $f, t /$ Capital $_{f, t-1}$ & -0.700 & 2.122 & -0.705 & -0.226 & -0.030 \\
\hline Sales growth $_{f, t-1}$ & 0.054 & 0.345 & -0.135 & -0.000 & 0.156 \\
\hline Bank Shock $_{f, t}$ & -0.068 & 0.115 & -0.143 & -0.080 & 0.001 \\
\hline Firm Shock $_{f, t}$ & 0.111 & 0.550 & -0.198 & -0.007 & 0.217 \\
\hline 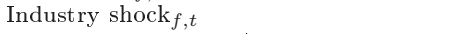 & 0.000 & 0.030 & -0.015 & 0.003 & 0.020 \\
\hline Mean Bank-Loan-to-Asset Ratio $_{f}$ & 0.216 & 0.253 & 0.072 & 0.165 & 0.293 \\
\hline Mean Other-Loan-to-Asset Ratio $f$ & 0.086 & 0.132 & 0.000 & 0.021 & 0.120 \\
\hline Mean Bond-to-Asset Ratio $_{f}$ & 0.040 & 0.105 & 0.000 & 0.000 & 0.000 \\
\hline Mean Intra-Group-Loan-to-Asset Ratio $f$ & 0.058 & 0.117 & 0.000 & 0.000 & 0.060 \\
\hline Mean Shareholder-Debt-to-Asset Ratio $f$ & 0.106 & 0.154 & 0.000 & 0.033 & 0.151 \\
\hline Employees $_{f, t}$ & 16.5 & 134.4 & 3 & 5 & 11 \\
\hline Sales $_{f, t}$ & $1,986,915$ & $34,556,706$ & 111,333 & 271,016 & 800,066 \\
\hline
\end{tabular}

\section{TABle A.2. Firm-Level Summary Statistics}

Notes: The variables are defined as follows. By year: Percent change in Flow of Funds $t$ is the year-on-year percent change in the stock of lending of private financial institutions to private non-financial corporations. Investment $t /$ Capital $_{t-1}$ is the net investment of the private sector excl. housing in year $t$ divided by the capital stock of year $t-1$. Percent Change in Private Investment $t$ is the year-on-year percent change in the total investment of the private sector excl. housing. Common Shock $t$ is the sum of the median firm shock and the median bank shock in each year. By bank: Bank shock $t$ is the idiosyncratic bank shock for each bank. Capital Adequacy Ratio $_{b, t}$ is the combined Tier 1 and Tier 2 capital divided by the banks' risk weighted assets. Growth Rate of Tier 1 Capital $_{b, t}$ is the yearon-year growth rate of banks' Tier 1 capital. Return on Assets $_{b, t}$ is the net income of bank $b$ over its average total assets. Return on Equity $_{b, t}$ is the net income of bank $b$ over its net assets. By Firm: Investment $f, t / \mathrm{Capital}_{f, t-1}$ is the each firm's year-on-year change in tangible fixed assets plus depreciation divided by the firm's tangible fixed assets in year $t-1$. Cash Flow $f, t /$ Capital $_{f, t-1}$ is firm $f$ 's cash flow divided by its tangible fixed assets in year $t-1$. Sales growth $f, t-1$ is the lag of firm $f$ 's percent change in sales. Bank Shock $f, t$ is the weighted sum of the idiosyncratic bank shocks of all banks from which firm $f$ was receiving a loan in year $t-1$. Firm Shock $f, t$ is the idiosyncractic shock for firm $f$. Industry Shock $_{f, t}$ is the industry level shock of firm $f$ 's industry. Mean Bank-Loan-to-Asset Ratio $f$ is firm $f$ 's mean ratio of total bank loans to total assets over the sample period. The ratios for Other Loans, Bonds, Intra-Group Loans and Liabilities towards Shareholders (LTS) are defined analogously. Employees $f, t$ is the total number of employees working for firm $f$ in year $t$. Sales $f, t$ is the total revenue of firm $f$ in year $t$. 


\section{WORKING PAPERS}

\section{3}

01|13 Macroeconomic forecasting using lowfrequency filters

João Valle e Azevedo | Ana Pereira

02|13 Everything you always wanted to know about sex discrimination

Ana Rute Cardoso | Paulo Guimarães | Pedro Portugal

03|13 Is there a role for domestic demand pressure on export performance?

Paulo Soares Esteves | António Rua

04|13 Ageing and fiscal sustainability in a small euro area economy

Gabriela Castro | José R. Maria | Ricardo Mourinho Félix | Cláudia Rodrigues Braz

05|13 Mind the gap! The relative wages of immigrants in the Portuguese labour market Sónia Cabral | Cláudia Duarte

06|13 Foreign direct investment and institutional reform: Evidence and an application to Portugal

Paulo Júlio | Ricardo Pinheiro-Alves | José Tavares

07|13 Monetary policy shocks: We got news! Sandra Gomes | Nikolay Iskrev | Caterina Mendicino

08|13 Competition in the Portuguese Economy: Estimated price-cost margins under imperfect labour markets

João Amador | Ana Cristina Soares

09|13 The sources of wage variation: a threeway high-dimensional fixed effects regression model

Sonia Torres | Pedro Portugal | John T. Addison | Paulo Guimarães
10|13 The output effects of (non-separable) government consumption at the zero lower bound

Valerio Ercolani | João Valle e Azevedo

11|13 Fiscal multipliers in a small euro area economy: How big can they get in crisis times?

Gabriela Castro | Ricardo M. Felix | Paulo Julio | Jose R. Maria

12|13 Survey evidence on price and wage rigidities in Portugal

Fernando Martins

13|13 Characterizing economic growth paths based on new structural change tests Nuno Sobreira | Luis C. Nunes | Paulo M. M. Rodrigues

14|13 Catastrophic job destruction Anabela Carneiro | Pedro Portugal | José varejão

$15 \mid 13$ Output effects of a measure of tax shocks based on changes in legislation for Portugal

Manuel Coutinho Pereira | Lara Wemans

16|13 Inside PESSOA - A detailed description of the model

Vanda Almeida | Gabriela Castro | Ricardo M. Félix | Paulo Júlio | José R. Maria

17|13 Macroprudential regulation and macroeconomic activity

Sudipto Karmakar

18|13 Bank capital and lending: An analysis of commercial banks in the United States Sudipto Karmakar | Junghwan Mok 


\section{4}

1|14 Autoregressive augmentation of MIDAS regressions

Cláudia Duarte

2|14 The risk-taking channel of monetary policy - exploring all avenues

Diana Bonfim | Carla Soares

3|14 Global value chains: Surveying drivers, measures and impacts

João Amador | Sónia Cabra

4|14 Has US household deleveraging ended? a model-based estimate of equilibrium debt

Bruno Albuquerque | Ursel Baumann | Georgi Krustev

5|14 The weather effect: estimating the effect of voter turnout on electoral outcomes in italy

Alessandro Sforza

6|14 Persistence in the banking industry: fractional integration and breaks in memory Uwe Hassler | Paulo M.M. Rodrigues | Antonio Rubia

7|14 Financial integration and the great leveraging Daniel Carvalho

8|14 Euro area structural reforms in times of a global crisis

Sandra Gomes

9|14 Labour demand research: towards a better match between better theory and better data

John T. Addison | Pedro Portugal | José Varejão
10|14 Capital inflows and euro area long-term interest rates

Daniel Carvalho | Michael Fidora

11|14 Misallocation and productivity in the lead up to the Eurozone crisis

Daniel A. Dias | Carlos Robalo Marquesz | Christine Richmond

12|14 Global value chains: a view from the euro area

João Amador | Rita Cappariello | Robert Stehrer

13|14 A dynamic quantitative macroeconomic model of bank runs

Elena Mattana | Ettore Panetti

14|14 Fiscal devaluation in the euro area: a model-based analysis

S. Gomes | P. Jacquinot | M. Pisani

15|14 Exports and domestic demand pressure: a dynamic panel data model for the euro area countries

Elena Bobeica | Paulo Soares Esteves | António Rua | Karsten Staehr

16|14 Real-time nowcasting the US output gap: singular spectrum analysis at work Miguel de Carvalho | António Rua 


\section{5}

1|15 Unpleasant debt dynamics: can fiscal consolidations raise debt ratios?

Gabriela Castro | Ricardo M. Félix | Paulo Júlio | José R. Maria

2|15 Macroeconomic forecasting starting from survey nowcasts

João Valle e Azevedo | Inês Gonçalves

3|15 Capital regulation in a macroeconomic model with three layers of default

Laurent Clerc | Alexis Derviz | Caterina Mendicino | Stephane Moyen | Kalin Nikolov | Livio Stracca | Javier Suarez | Alexandros P. Vardoulakis

4|15 Expectation-driven cycles: time-varying effects

Antonello D'Agostino | Caterina Mendicino

5|15 Seriously strengthening the tax-benefit link

Pedro Portugal | Pedro S. Raposo

6|15 Unions and collective bargaining in the wake of the great recession

John T. Addison | Pedro Portugal | Hugo Vilares

7|15 Covariate-augmented unit root tests with mixed-frequency data

Cláudia Duarte

8|15 Financial fragmentation shocks

Gabriela Castro | José R. Maria | Paulo úlio | Ricardo M. Félix

9|15 Central bank interventions, demand for collateral, and sovereign borrowing cost Luís Fonseca | Matteo Crosignani | Miguel Faria-e-Castro
10|15 Income smoothing mechanisms after labor market transitions

Nuno Alves | Carlos Martins

11|15 Decomposing the wage losses of displaced workers: the role of the reallocation of workers into firms and job titles Anabela Carneiro | Pedro Raposo | Pedro Portugal

12|15 Sources of the union wage gap: results from high-dimensional fixed effects regression models

John T. Addison | Pedro Portugal | Hugo Vilares

13|15 Assessing european firms' exports and productivity distributions: the compnet trade module Antoine Berthou | Emmanuel Dhyne | Matteo Bugamelli | Ana-Maria Cazacu | Calin-Vlad Demian | Peter Harasztosi | Tibor Lalinsky | Jaanika Meriküll | Filippo Oropallo | Ana Cristina Soares

14|15 A new regression-based tail index estimator: an application to exchange rates

João Nicolau | Paulo M. M. Rodrigues

15|15 The effect of bank shocks on firm-level and aggregate investment João Amador | Arne J. Nagengast 


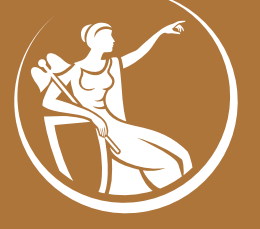

